\title{
Regenerative potential of the soil seed bank along an elevation gradient of rupestrian grassland in Southeastern \\ Brazil
}

\begin{tabular}{|c|c|}
\hline Journal: & Botany \\
\hline Manuscript ID & cjb-2017-0162.R1 \\
\hline Manuscript Type: & Article \\
\hline Date Submitted by the Author: & 07-Nov-2017 \\
\hline Complete List of Authors: & $\begin{array}{l}\text { Luz, Giovana; Universidade Federal de Minas Gerais, Programa de Pós- } \\
\text { graduação em Ecologia, Conservação e Manejo da Vida Silvestre } \\
\text { Mota, Graciene; Universidade Federal de Lavras, Departamento de Ciências } \\
\text { Biológicas } \\
\text { Spadeto, Cristiani; Universidade Federal de Minas Gerais, Programa de } \\
\text { Pós-graduação em Ecologia, Conservação e Manejo da Vida Silvestre } \\
\text { Tolentino, Gláucia; Universidade Estadual de Montes Claros, Laboratório de } \\
\text { Ecologia Vegetal } \\
\text { Fernandes, Geraldo; Universidade Federal de Minas Gerais, Biologia Geral } \\
\text { Nunes, Yule Roberta; Universidade Estadual de Montes Claros, Biologia } \\
\text { Geral }\end{array}$ \\
\hline $\begin{array}{r}\text { Is the invited manuscript for } \\
\text { consideration in a Special } \\
\text { Issue? : }\end{array}$ & N/A \\
\hline Keyword: & $\begin{array}{l}\text { elevation, beta-diversity, floristic similarity, natural regeneration, edaphic } \\
\text { variables }\end{array}$ \\
\hline
\end{tabular}




\section{Regenerative potential of the soil seed bank along an elevation gradient of rupestrian grassland in Southeastern Brazil}

Giovana Rodrigues da Luz ${ }^{1}$, Graciene da Silva $\mathrm{Mota}^{2}$, Cristiani Spadeto ${ }^{1}$, Gláucia Soares Tolentino ${ }^{3}$, G. Wilson Fernandes ${ }^{1}$ and Yule Roberta Ferreira Nunes ${ }^{3}$

${ }^{1}$ Programa de Pós-graduação em Ecologia, Conservação e Manejo da Vida Silvestre, Universidade Federal de Minas Gerais, Av. Presidente Antônio Carlos 6627, 31270-910 Belo Horizonte, Minas Gerais, Brazil

(giovanaluz@gmail.com, cristianispadeto@gmail.com,gw.fernandes@gmail.com)

${ }^{2}$ Departamento de Ciências Biológicas, Universidade Federal de Lavras, Campus Universitário, Caixa Postal 3037, 37200-000, Lavras, Minas Gerais, Brazil (gracibiounimontes@yahoo.com.br)

${ }^{3}$ Laboratório de Ecologia Vegetal, Departamento de Biologia Geral, Universidade Estadual de Montes Claros, Campus Universitário Prof. Darcy Ribeiro, Caixa Postal 126, 39401-089, Montes Claros, Minas Gerais, Brazil (glaucia.tolentino@gmail.com, yule.nunes@unimontes.br)

*Author for Correspondence

Dr. Yule R. F. Nunes

Universidade Estadual de Montes Claros, Laboratório de Ecologia Vegetal Montes Claros, Minas Gerais, Brazil

39401-089

yule.nunes@unimontes.br 


\begin{abstract}
The objective of this study was to determine the species richness and abundance of seed bank and the influence of soil attributes along an elevation gradient (800-1400 m). We examined floristic similarity among areas and determined the regional diversity along this gradient in Serra do Cipó (Brazil). A total of 1975 individuals of 149 species were germinated. Richness and abundance were not linearly related to elevation and exhibited a threshold at $1200 \mathrm{~m}$. The low degree of similarity among the areas reflects environmental heterogeneity, resulting from a rich mosaic of habitats, distinguished by the substrate configuration, continuity of vegetation, floristic composition, and proportion of exposed rock. Diversity between plots of different areas $(\beta 2)$ contributed to regional diversity, and species turnover was the most important factor. The physical variables and base saturation which had high spatial heterogeneity may be the most important factors to determine species turnover and $\beta$ diversity. The studied seed bank is strongly influenced by edaphic variables, with a gradient of increasing acidity and proportion of fine sand, and decreasing proportion of clay and organic matter, with elevation. In addition, species richness was influenced by cation exchange capacity, organic matter and clay and abundance by cation exchange capacity, $\mathrm{H}+\mathrm{Al}$, organic matter and base saturation.
\end{abstract}

Keywords: Elevation; Beta-diversity; Floristic similarity; Natural regeneration; Edaphic variables.

\title{
Introduction
}

Mountains possess great biodiversity and high levels of endemism, and are considered unique environments for detecting the impacts of global climate change (Spehn et al. 2010). Elevation is correlated with a wide variety of factors that influence 
plant establishment and regulation, including precipitation, climatic variation and soil characteristics (Kharkwal et al. 2005; Sharma et al. 2009). Decades of research has led to general hypotheses regarding species distribution along elevation gradients, with one of the most reported patterns being a decrease in plant species richness with increased elevation (e.g., Whittaker 1956; Hamilton 1975; Gentry 1988; Toledo-Garibaldi and Williams-Linera 2014). At higher elevations, temperature, wind and soil instability may limit plant growth (Callaway et al. 2002). However, the seed bank does not seem to be a single standard for richness and abundance in relation to altitude. Cummins and Miller (2002), studying Calluna vulgaris in Scotland, did not find significant variation of seed density as a function of altitude. These authors concluded that soil fertility and seed rain (authochthonous and allochthonous seeds that are dispersed in the area) had a greater influence than altitude. Funes et al. (2003), studying seed bank on a mountain in the central region of Argentina, found an increase in richness and density with increasing altitude. Ortega et al. (1997), studying seed bank in a gradient in Spain, found an inverse result, with increased richness in the lower areas and dominance of annual species, and a decrease in the higher areas and dominance of perennial species. The lack of altitudinal pattern of soil seed banks (see also Lippok et al. 2011; Oke and Okunola 2008) reinforces the importance of studies of regenerative potential in the soil of mountaintops regions.

The Serra do Cipó is a mountainous region in Brazil, whose predominant vegetation is the rupestrian grasslands (locally called campos rupestres), associated with quartzite formations. They form a mosaic of plant communities adapted to the environmental constraints provided by its highly infertile soils, and have high levels of aluminum and due to a pronounced seasonal drought, intense light exposure, and strong and constant winds (Benites et al. 2007; Negreiros et al. 2009; Carvalho et al. 2012). 
This phytophysiognomy is one of the most studied grasslands in Brazil, especially with regard to its flora (e.g., Giulietti et al. 1987; Conceicão and Pirani 2005, 2007; Rapini et al. 2008; Borges et al. 2011). Studies of established vegetation in this area, for both woody and rosette species (Mota et al. 2017), and natural regeneration (Mota et al. 2016) have shown a pattern of decreasing species richness and abundance with increasing elevation. In these studies, the process of species turnover was the determining factor for diversity, as well as the greater floristic similarity between areas of similar elevations. In addition, some edaphic variables (mainly phosphorus and base saturation) were found to be determinants of vegetation distribution (Mota et al. 2016, 2017).

Several studies reveal the vulnerability of rupestrian grasslands to global climate change (Bitencourt et al. 2016), biological invasions (Barbosa et al. 2010), increased pressure on natural resources (Fernandes et al. 2014), because the vegetation is very diverse and exhibits great variability in species composition. Investigations of the processes and patterns involved in the natural regeneration of rupestrian grasslands, and the factors that determine species colonization, are needed (Mota et al. 2016). The potential regeneration of an area is influenced by seed rain, seed and seedling banks and regrowth of individuals (Garwood 1989). Species composition and abundance of seed banks vary with the degree of disturbance and, as a consequence of geographic location, elevation, climate and soil (Williams-Linera 1993; Cummins and Miller 2002). Due to high elevation, irregular relief and the presence of rocky outcrops, the soils of rupestrian grasslands possess a high erosion index (Benites et al. 2003). Loss of soil structure results in difficulties in absorption and retention of rainwater and soil reserves, leading to desiccation of seeds and loss of germination capacity (Carmo et al. 2012). Gulshan and Dasti (2012) showed that soil composition plays an important role in seed 
germination. The influence of soil on seed germination is based on the transmission of light through the soil, which includes particle size, moisture content, particle color and the presence of organic matter (Tester and Morris 1987). These data reinforce our hypothesis that the soil physical and chemical characteristics influence the germination of the seeds that are buried in the soil, composing the seed bank. Thus, even at shallow depths, sometimes formed only of an organic layer upon rock, soils in these highmountain areas represent an important factor for the occurrence of vegetation (Benites et al. 2001). On the other hand, studies on the regenerative potential of rupestrian grasslands through the soil seed bank are still rare (Medina and Fernandes 2007; Le Stradic 2012).

We investigated the composition, richness, abundance, and diversity ( $\alpha$ and $\beta$ ) of the seed bank along a seven areas at different elevations. We also evaluated similarity in the composition of the seed bank among different areas and the influence of edaphic factors on the distribution of species. Therefore, we aimed to answer the following questions: (i) do richness and abundance of seed in the soil seed bank decrease linearly with increasing elevation? (ii) is local diversity $(\alpha)$ lower than the diversity among areas $(\beta)$, and is the process of turnover the main source of variation in beta diversity throughout the elevation gradient? (iii) is there greater floristic similarity among areas more proximate altitudinally than among areas more proximate geographically? and (iv) does soil influence the composition and distribution of seed bank species along the gradient analyzed? We expected the seed bank to exhibit the same general patterns observed for aboveground vegetation in relation to elevation, soil variables and, consequently, distribution of diversity.

\section{Methods}




\section{Study area}

The study was conducted in areas of rupestrian grasslands in Serra do Cipó, located in the southern portion of the Serra do Espinhaço $\left(19^{\circ} 12^{\prime}-19^{\circ} 34^{\prime} \mathrm{S}, 43^{\circ} 27^{\prime}-\right.$ $43^{\circ} 38^{\prime} \mathrm{W}$ ), in the central area of the state of Minas Gerais, Southeastern Brazil (Fig. 1). The region has a highland tropical Cwb Köppen climate with a rainy season between November and February and mean annual temperature and rainfall of $20^{\circ} \mathrm{C}$ and 1,500 mm, respectively (Madeira and Fernandes 1999). The rainy season is concentrated from November to February, while the dry season is most pronounced from June to August (Fernandes et al. 2016). The sampling area was delimited along an elevation gradient with seven sampling areas: 800, 900, 1000, 1100, 1200, 1300 and $1400 \mathrm{~m}$ a.s.1. (for more details see Mota et al. 2016, 2017). The areas of 800, 900 and $1000 \mathrm{~m}$ were considered low-elevation areas, 1100 and $1200 \mathrm{~m}$ as intermediate, and 1300 and 1400 $\mathrm{m}$, as high-elevation areas.

\section{Seed bank sampling}

Seed bank sampling was performed during four periods: July 2014, February 2015, September 2015, and February 2016. Data gathered from the four sampling periods were then assembled in only one database. Therefore, we analysed all results as only one data record. At each area, 13 plots $\left(100 \mathrm{~m}^{2}\right)$, spaced $10 \mathrm{~m}$ from each other, previously installed to survey woody vegetation (Mota et al. 2017) were sampled. In each plot, four equidistant points were marked at $3 \mathrm{~m}$ from the plot edge. Samples of superficial litter and soil were collected at the depth of $0-5 \mathrm{~cm}\left(4500 \mathrm{~cm}^{3}\right)$, using a 30 $\mathrm{cm} \times 30 \mathrm{~cm}$ template. A total of four soil samples and four litter samples were collected per plot and combined to form one composite plot sample for each category (litter and soil). The litter and soil samples of each plot were then divided into two and packed in 
plastic trays $(22 \mathrm{~cm} \times 12 \mathrm{~cm} \times 8 \mathrm{~cm})$. The litter samples were arranged on sterilized sand, according to the methodology adapted from Pereira et al. (2010).

In order to assess species germination, for each sampling period each pair of soil and litter samples were distributed in greenhouses on the campus of Universidade Estadual de Montes Claros (Unimontes), in Montes Claros (Minas Gerais, Brazil), under two light conditions (direct light and 50\% shade). Fifty-six plastic trays containing sterile sand were also distributed in each greenhouse to control for contamination by the local seed rain. Four such control trays were added to each treatment, formed by 13 trays containing soil or litter collected in each plot of the seven areas. All samples were irrigated twice a day (once during the morning and once in the afternoon).

The germination method (Brown 1992) was used to evaluate the seed bank. Samples from each area were monitored weekly during a 12-week period by counting and morphotyping all individuals that sprouted. After plant establishment, or with the appearance of reproductive structures, individuals were removed, herborized, identified, and deposited in the Montes Claros Herbarium (MCMG) of Unimontes. Identification of the botanical material was performed with the assistance of experts and specialized botanic literature. The classification of species into families followed Angiosperm Phylogeny Group IV system (APG IV 2016).

\section{Physicochemical soil analysis}

The relationship between the seed bank and the physicochemical composition of the soil was done using data collected by Mota et al. (2016) in 2012. Samples composed of superficial soil $(0-20 \mathrm{~cm}$ in depth) of each plot were analyzed according to the protocol of Embrapa (1997), which included measuring $\mathrm{pH}$ (pH in water), $\mathrm{K}$ (levels of 
potassium), P-Mehlich (phosphorus), P-rem (remaining phosphorus), Ca (calcium), Mg (magnesium), Al (aluminum), $\mathrm{H}+\mathrm{Al}$ (potential soil acidity), $\mathrm{SB}$ (sum of bases), $\mathrm{V}$ (base saturation), $\mathrm{t}$ (effective cation exchange capacity), $\mathrm{m}$ (aluminum saturation), $\mathrm{T}$ (cation retention capacity), OM (organic matter), and proportions of clay $(<0.02 \mathrm{~mm}$ ), silt $(0.02-0.05-\mathrm{mm})$, fine sand $(0.05-0.2 \mathrm{~mm})$ and coarse sand $(0.2-2 \mathrm{~mm})$.

\section{Data analysis}

Species composition

Cumulative values of abundance and species richness were determined for each plot at each elevation addressing the four sampled periods. Individuals who died during the experiment were included only in the calculation of abundance. To determine if variation in elevation determined abrupt changes in species richness and abundance, we used the segmented function of the 'segmented' package (Muggeo 2008), applying the glm.nb function of the MASS package (Ripley et al. 2017), with negative binomial error distribution for the overdispersion of the count data. This analysis tests for the existence of ecological thresholds that occur when a model with a breakpoint explains more variation than a linear model (Magnago et al. 2015). To determine if elevation influenced richness and abundance, we constructed Generalized Linear Models (GLMs) in which levels of elevation were grouped through contrast analysis (Crawley 2013). If the level of aggregation was not significant, and did not change the deviation explained by the null model, the levels were pooled. The models were submitted to residual analysis to identify the most appropriate error distribution. These analyses were performed within the R environment (R Core Team 2015).

\section{Beta Diversity}


To evaluate differences in species composition among areas (beta diversity), we carried out an additive partitioning analysis (Veech et al. 2002). In additive partitioning, $\gamma=\alpha+\beta$, with $\alpha$ (alpha diversity) representing the diversity within each plot, $\beta$ (beta diversity) the diversity among plots of different areas and $\gamma$ (gamma diversity) the diversity of the entire gradient analyzed. The $\beta$ diversity was divided into $\beta 1$ (diversity among plots at the same area), and $\beta 2$ (species turnover among areas at different areas). Diversities $\alpha$ and $\beta$ were calculated using the sampled species richness of the seven areas at different elevations using the 'Vegan' package (Oksanen et al. 2017) within $\mathrm{R}$ environment ( $\mathrm{R}$ Core Team 2015). A method using 1,000 randomizations was applied to measure the divergence between observed values and the null model for three diversity components used here $(\alpha, \beta 1$ and $\beta 2)$.

For partitioning $\beta 2$ diversity, we used the beta.multi function (using the Sørensen index) of the 'Betapart' package (Baselga and Orme 2012). In order to determine which component was the main feature of $\beta$ diversity - nestedness (species accumulation) or turnover (species substitution) - $\beta$ diversity was determined using the Sørensen $\left(\beta_{\mathrm{SOR}}\right)$ and Simpson $\left(\mathrm{B}_{\mathrm{SIM}}\right)$ indices (Baselga 2010). $\mathrm{B}_{\mathrm{SOR}}$ represents total $\beta$ diversity and includes both turnover and nestedness. $\mathrm{B}_{\mathrm{SIM}}$ does not consider differences in species richness and, therefore, represents only the spatial substitution of species, or turnover. Thus, the total loss of species due to nestedness $\left(\beta_{\mathrm{NES}}\right)$ is given by the difference between these indices $\left(\beta_{\mathrm{NES}}=\beta_{\mathrm{SOR}}-\beta_{\mathrm{SIM}}\right)$.

\section{Similarity among areas}

The similarity of seed-bank species composition among areas (800 to $1400 \mathrm{~m}$ ) was determined through the non-metric multidimensional scaling (NMDS) using the Sorensen similarity index (Hammer 2012), calculated from species presence/absence 
matrices in PCORD for Windows, Version 6.0 (McCune and Mefford 1999). Analysis of variance (ANOVA) and the Tukey test were used to compare the axes obtained from NMDS among areas. Area was used as the explanatory variable and axes as the response variable. In order to verify if the most similar areas are those that have the smaller geographical distance between them, the geographical distance between the areas was measured in kilometers with the aid of the software Google Earth Pro Version 7.3.3832, using the geographical coordinate's data of each area.

Soil analysis

To compare soil variables among areas, GLMs were constructed using $\mathrm{pH}, \mathrm{K}, \mathrm{P}-$ Mehlich, $\mathrm{P}, \mathrm{Ca}, \mathrm{Mg}, \mathrm{Al}, \mathrm{H}+\mathrm{Al}, \mathrm{SB}, \mathrm{V}, \mathrm{t}, \mathrm{m}, \mathrm{T}, \mathrm{OM}$, and proportions of coarse sand (CS), fine sand (FS), silt and clay as response variables and areas as predictor variable. When significant differences were observed among areas, the data were submitted to contrast analysis through the aggregation of levels (Crawley 2002). All models were submitted to residual analysis to identify the most appropriate error distribution (Crawley 2002). To test if the physicochemical properties of the soil influence the distribution of seed bank species in different elevations, a canonical correspondence analysis (CCA) was performed in PCORD for Windows Version 5.0 (McCune and Mefford 1999). Only the species with more than 10 individuals were used, which was equivalent to 30 species, 15 identified at the species level, 11 at the genus level and 4 at the family level. After the preliminary CCA, the non-significant soil variables and those with high redundancy $(>0.5)$ were eliminated, keeping only the soil properties that had a close relationship with species abundance: cation exchange capacity (t), base saturation $(\mathrm{V})$, organic matter $(\mathrm{OM})$, potential soil acidity $(\mathrm{H}+\mathrm{Al})$, proportion of fine 
sand (FS) and proportion of clay. The Monte Carlo permutation test was used to evaluate the significance of the model (Ter Braak 1987).

To investigate the effect of edaphic variables on seed bank richness and abundance at each elevation, GLMs were constructed with the variables selected through the CCA $(>0.5)$. Thus, the global model included potential soil acidity $(\mathrm{H}+$ $\mathrm{Al}$ ), effective cation exchange capacity $(\mathrm{t})$, base saturation $(\mathrm{V})$, organic matter (OM), fine sand and clay as predictor variables. Within the $\mathrm{R}$ environment ( $\mathrm{R}$ Core Team 2015), GLMs (Generalized Linear Models) were created using the glm.nb function of the MASS package (Ripley et al. 2017), with negative binomial error distribution for the overdispersion of the count data. Using the dredge function of the 'MuMIn' package (Bartón 2016), all possible combinations of the variables included in the global model were tested, with the most decisive factors for richness and abundance being identified through the AICc (Akaike's Information Criteria of Second Order), with the best model being the one with the lowest AICc value (Burnham et al. 2011).

In order to verify if the soil attributes are spatially stratified, the analysis of stratified spatial heterogeneity was performed. The value of $q$ indicates the percent of the variance of an attribute explained by the stratification, in which 0 indicates no spatial stratified heterogeneity and 1 indicates perfect spatial stratified heterogeneity (Wang et al 2016). So, $q$-values were calculated in order to demonstrate how soil variables were spatially stratified.

\section{Results}

Richness and abundance of soil seed bank along elevation gradient

A total of 1975 individuals were recruited in the soil seed bank, representing 22 families and including 149 taxa. Of these taxa, 41 were identified to the species level, 
55 to genus and 44 to family, while nine remained unidentified (Table A1). The dominant families were Poaceae (40 species), Cyperaceae (35), Melastomataceae (14) and Asteraceae (12). The most abundant species were Rhynchospora consanguinea (354 individuals), R. riedeliana (154), Rhynchospora sp.3 (129), Rhynchospora sp.4 (139) and Bulbostylis sp. (90), which together comprised $42 \%$ of germinated individuals.

Species richness and abundance did not show a linear relationship with elevation ( $\mathrm{p} \geq$ 0.05). Instead, a threshold for richness (Fig. 2a) and abundance (Fig. 2b) was identified through finding a breakpoint at the elevation of $1200 \mathrm{~m}$ (Table 1), which showed an abrupt decrease for richness and abundance from this altitude onwards. Both richness $\left(F_{6.84}=53.621, p \leq 0.001\right.$; Fig. $\left.3 \mathrm{a}\right)$ and abundance $\left(F_{6,84}=80,663, p \leq 0.00\right.$; Fig. $\left.3 \mathrm{~b}\right)$ varied among areas. The seed bank at areas of 800, 900, 1100 and $1200 \mathrm{~m}$ had greater richness than at 1000, 1300 and $1400 \mathrm{~m}$. The highest abundance was observed at 1200 $\mathrm{m}$ and the lowest at $1300 \mathrm{~m}$; abundance did not differ among 800, 900, 1000, 1100 and $1400 \mathrm{~m}$.

Variation in beta diversity along elevation gradient

The additive partitioning of species diversity revealed that gamma diversity $(\gamma)$ is formed mainly by species turnover between areas $(\beta 2=70 \%)$, followed by species turnover among the plots of the same area $(\beta 1=24.5 \%)$. Local diversity $(\alpha)$ represented only $5.8 \%$. Thus, beta diversity $(\beta)$ represented $94.5 \%$ of the regional diversity of the seed bank in the studied area. The three components of diversity were statistically different from that expected by the null model (Fig. 4). The observed value for $\beta 1$ was lower than that expected by chance, while the observed values of $\beta 2$ and $\alpha$ were higher. The decomposition of $\beta 2$ diversity revealed that species turnover between areas is the 
main component of $\beta_{\mathrm{SOR}}$ diversity $\left(\beta_{\mathrm{SOR}}=0.61, \beta \operatorname{sim}=0.49\right)$, representing $81 \%$ of $\beta$ diversity; nestedness explained only $19 \%(\beta$ nes $=0.11)$.

Floristic similarity between areas and elevations

The NMDS ordering analysis showed (Fig. 5) that areas which are more proximate altitudinally had greater similarity than areas more proximate geographically (Supplementary data, Table S1). As can be seen in Figure 5, that areas, at 800 and 900 $\mathrm{m}$, although having one of the largest geographical distances (almost $10 \mathrm{~km}$ distance), approached each other. Similarly, areas at 1300 and $1400 \mathrm{~m}$ (which is $6.03 \mathrm{~km}$ apart) also approached each other, and the intermediate areas of 1000, 1100 and $1200 \mathrm{~m}$ approached each other, regardless of the geographical distance between them. The first axis segregated the lower areas $(800$ and $900 \mathrm{~m})$ from the highest areas (1300 and 1400 $\mathrm{m})$, while intermediate areas $(1000,1100$ and $1200 \mathrm{~m})$ remained scattered between both groups. The first axis $(F=2.89, P \leq 0.05)$ and the second axis $(F=5.62, P \leq 0.05)$ revealed a significant correlation with the elevation composition. However, Tukey HSD (honestly significant difference) test found no significant differences among areas and, therefore, indicated low similarity. Only six species were common to all areas: $R$. consanguinea, $R$. riedeliana, Rhynchospora sp.3, Rhynchospora sp.4, $R$. tenuis and Echinolaena inflexa.

Soil attributes and distribution of seed bank along the elevation gradient

The soil analysis indicated that all analyzed parameters varied significantly among areas (Table 2). The $q$-values indicated that soil variables were spatially stratified at least to some degree. $\mathrm{pH}$ was the soil attribute that was least heterogeneous (0.23), compared to base saturation, which was the variable with the highest spatial 
stratified heterogeneity (0.69). Despite to base saturation, the physical attributes were variables with highest spatial stratified heterogeneity. In general, the soils were acid, especially those at intermediate and high altitudes $(\mathrm{pH}<4.99)$. The area of $1300 \mathrm{~m}$ possessed a lower concentration of potassium, while the areas at 800 and $1400 \mathrm{~m}$ had higher values of magnesium. The areas at 1200 and $1400 \mathrm{~m}$ possessed higher values of aluminum, whereas $1400 \mathrm{~m}$ possessed higher values of calcium. Base saturation was higher at $800 \mathrm{~m}$, while the sum of bases did not differ between the areas of 800 and $1400 \mathrm{~m}$. The effective cation exchange capacity was lowest at $1300 \mathrm{~m}$ and highest at $1400 \mathrm{~m}$, while aluminum saturation was highest at $1200 \mathrm{~m}$ and lowest at $800 \mathrm{~m}$. The highest levels of organic matter were found at 1200 and $1400 \mathrm{~m}$, and the lowest at 800 and $1000 \mathrm{~m}$. Regarding physical variables, the areas at 800 and $900 \mathrm{~m}$ had a lower amounts of fine sand and greater amounts of silt, while the area at $900 \mathrm{~m}$ also exhibited a greater amount of clay.

The first two axes of the CCA (Fig. 6) possessed eigenvalues of 0.32 (axis 1) and 0.23 (axis 2), and explained $5.8 \%$ and $4.2 \%$ of the total data variance, respectively. The eigenvalues for the two ordination axes were low, indicating that there is low species substitution along the gradient. On the other hand, species-environment correlations were high for both axes: 0.81 (axis 1) and 0.79 (axis 2). Furthermore, the Monte Carlo permutation test indicated that abundance was significantly correlated with soil attributes $(\mathrm{p}<0.05)$.

Plots located at different areas were segregated, and the organization of these plots formed three groups (Fig. 6a). The first group, in axis 1, comprised plots at 1300 and some at $1400 \mathrm{~m}$; the second group, in axis 2, comprised plots at elevations of 800 and 1100 , and some at $900 \mathrm{~m}$; and the third group, in axis 1, comprised plots at 1000 and 1200 , and some at $1400 \mathrm{~m}$. Internal correlations between environmental variables 
and the first two ordination axes (Table 3) showed that the environmental variables most strongly correlated with axis 1 were clay (positive correlation); $\mathrm{H}+\mathrm{Al}, \mathrm{t}$ (effective cation exchange capacity), OM (organic matter) and fine sand (negative correlation), while the environmental variable most strongly correlated with axis 2 was $\mathrm{V}$ (base saturation), which exhibited a negative correlation. The seed bank at all plots located at $1300 \mathrm{~m}$, and some at $1400 \mathrm{~m}$, was positively correlated with the variables V and clay. Most of the plots at $1100 \mathrm{~m}$ were negatively correlated to organic matter, while those at $1000 \mathrm{~m}$ were positively related. Those located at $1200 \mathrm{~m}$ were positively correlated with $\mathrm{H}+\mathrm{Al}, \mathrm{t}$ and fine sand, and negatively correlated with V and clay; and some plots of the areas 800,900 and $1000 \mathrm{~m}$ were dispersed.

The CCA ordination of species (Fig. 6b) suggests that Symphyopappus brasiliensis, Paspalum multicaule, Digitaria cf. bicornis, Schwenkia americana., Phylanthus sp., Rhichardia sp.2 and Cyperus sp.3 are more abundant in areas with higher availability of clay and base saturation, while Baccharis platypoda, Polygala glochidiata, $R$. consaguinea and Bulbostylis sp. are more related to areas with a greater amount of organic matter. On the other hand, $R$. tenuis subsp. austro brasiliensis, $R$. riedeliana, Axonopus sp.3 and Borreria sp. are predominant in areas with low organic matter content. Homolepis longispicula, Schyzachyrium tenerium, and Eragrostis articulata were found related to areas with higher potential acidity, effective cation exchange capacity and a greater amount of fine sand.

Species richness at 1000, 1100 and $1200 \mathrm{~m}$ was affected mainly by effective cation exchange capacity $(\mathrm{t})$, at areas 1100 and $1300 \mathrm{~m}$ by organic matter $(\mathrm{OM})$, and at $1100 \mathrm{~m}$ clay. Seed abundance was affected mainly by the variable $\mathrm{t}$ at $1100 \mathrm{~m}, \mathrm{OM}$ at 1100 and $1300 \mathrm{~m}$, clay at $1100 \mathrm{~m}, \mathrm{H}+\mathrm{Al}$ at $1400 \mathrm{~m}$, and base saturation (V) at $1200 \mathrm{~m}$. None of the environmental variables analyzed explained the variation in species 
richness and abundance of germinated seeds at 800 and $900 \mathrm{~m}$, abundance at $1000 \mathrm{~m}$ and richness at $1400 \mathrm{~m}$ (Supplementary data, Table S2).

\section{Discussion}

Do richness and abundance of seed in the soil seed bank decrease with elevation?

Richness and abundance of the soil seed bank did not decrease with the increasing elevation, according to the adult woody and regenerating vegetation in the same areas/plots of this study (Mota et al. 2016, 2017). The results also do not corroborate general patterns of the distribution of plant diversity, which indicate decrease in richness with increasing elevation (e.g. Whittaker 1956; Hamilton 1975; Gentry 1988; Kitayama, 1992; Aiba and Kitayama, 1999; Hussain and Malik, 2012; Shaheen et al., 2015). However, several studies have shown a non-unimodal pattern for plant richness along elevation gradients (Lieberman et al. 1996; Wang et al. 2002; Joly et al. 2012), while others describe a peak of diversity at intermediate elevations (Fernandes 1992; Lomolino 2001; Sang 2009). In fact, there was an increase in abundance up to $1200 \mathrm{~m}$ and a stabilization of richness between 800 to $1200 \mathrm{~m}$, while above this elevation both abundance and richness decreased. This threshold at the intermediate elevation of $1200 \mathrm{~m}$ may be related to both the environmental conditions provided by the elevation and the composition of species present in the area. For example, the greater abundance at $1200 \mathrm{~m}$ may be related to the occurrence of species of the genus Rhynchospora and Bulbostylis, which comprised $44 \%$ of the observed total abundance. Both genera belong to the family Cyperaceae, which preferentially occurs on poorly drained soils such as swamps, marshes, river banks and puddles (Ardissone 2014). In some of the plots in the area of $1200 \mathrm{~m}$ the soil was flooded, which may have 
influenced the abundance of these species. This finding indicates that there is variation in the pattern of distribution of plant species by stratum along the studied gradient.

Elevation modifies the climatic conditions, influencing the composition, richness, abundance, and density of seeds in the soil (Funes et al. 2003; Ma et al. 2010; Lippok et al. 2013). The lower richness and abundance in the higher areas (1300 and $1400 \mathrm{~m})$ may be associated with low temperatures and, consequently, low embryonic metabolic rates and slow consumption of seed reserves, favoring greater seed longevity (Murdoch and Ellis 1992). However, other factors can act on the soil seed bank in response to variation in elevation, such as seed rain potential, soil type and conditions, presence of anthropic activities and evaluated seasons, among others (Cummins and Miller 2002; Funes et al. 2003; Ma et al. 2010; Lippok et al. 2013). For example, there was low richness and abundance in the area at $1000 \mathrm{~m}$. Soil type and area steep declivity of the terrain may facilitate the transport of seeds to lower regions, thereby changing the deposition of seed rain on this site.

Is local diversity $(\alpha)$ lower than the diversity among areas $(\beta)$, and is the process of turnover the main source of variation in beta diversity throughout the gradient analyzed?

Our results corroborate the hypothesis that diversity among areas $(\beta)$ contributes more to regional diversity $(\gamma)$ than does local diversity $(\alpha)$. This greater contribution of $\beta$ diversity to $\gamma$ diversity means that more species are added to the community due to differences in composition between plots within the same area and between areas of different elevations (see Veech et al. 2002). In addition to differing from that expected by chance, $\beta$ diversity was higher, indicating that this diversity component contributed to the global richness of seed bank species in the studied gradient. Although $\alpha$ diversity 
had a small contribution to regional diversity, local conditions are also important and cannot be disregarded when assessing the regional species pool (Cain et al. 2011). In this way, the partition of diversity should not be restricted to the scale of the landscape, and regional subsets should be considered to better understand the environment as a whole (Marques and Schoereder 2013). However, the value of $\beta 1$ being below the value expected by chance indicates that there is a high degree of similarity in species between plots of the same area, and structure and habitat conditions as a whole (Beck et al. 2012; Neves et al. 2013). The component $\beta 2$ contributed more to $\gamma$ diversity than $\beta 1$ and $\alpha$, with $70 \%$ of the seed bank diversity being caused by differences between areas. In association with this, turnover was the main component of $\beta 2$ diversity decomposition, indicating that mountain-top communities are not nested subsets of communities of lower elevations, but instead are communities with different species compositions. This result could be related to the high level of environmental heterogeneity of the sampled areas, with different types of habitats being found within a single area (Carvalho et al. 2012; Mota et al. 2016, 2017). We can also assume that diversity along the gradient can be shaped by different environmental filters that act on the exclusion or inclusion of species in certain communities (Cain et al. 2011). Thus, the dispersal ability of species, and their local abiotic conditions and species interactions, for example, can act as filters, causing differences in species composition between areas and increasing turnover along the studied gradient. Other studies with plants and other taxa, like insects, also point to turnover as the main component of $\beta 2$ diversity (Marques and Schoereder 2013; Nunes et al. 2016a; Mota et al. 2017). These data showed that the seed bank of the Serra do Cipó presents high regional diversity, caused by differences among areas, with high species turnover. 
Is there greater floristic similarity between more proximate altitudinally areas than among areas more proximate geographically?

The low degree of similarity found in the seed bank between areas, even among those closest to each other, is contrary to what was expected and observed in studies carried out for woody plant community in the areas (Mota et al. 2016, 2017). These results reflect environmental heterogeneity and the influence of edaphoclimatic factors on the composition of rupestrian grassland species (Carvalho et al. 2012).

Seed dispersal is an important step in the reproductive cycle of most plants, through which seed distribution occurs among diverse habitats, and can promote their deposition in particular sites suitable for germination and seedling establishment (Howe and Smallwood 1982). However, even when taken to adjacent areas, away from the mother plant, many seeds can not germinate and establish. Several factors contribute to the reproductive success of the diaspore, such as soil conditions, temperature, water conditions, light, and presence of dormancy (Nunes et al. 2016b). Altitude modifies climate interfering in several of these factors and thus in the composition and establishment of the plants (Kharkwal et al. 2005; Sharma et al. 2009). In this study, altitude was more important than geographic proximity for floristic similarity. In addition, the close similarity between the areas of 800 and $900 \mathrm{~m}$ and of 1300 and 1400 $\mathrm{m}$ may be related to physiognomic characteristics. Both lower areas have a predominance of shrub-tree species characteristic of the cerrado sensu stricto, with a transition to the rupestrian grasslands (Mota et al. 2017). Likewise, areas at higher elevations have a predominantly grassy, herbaceous stratum with few shrub species in rocky outcrops in these areas (Mota et al. 2017). Both areas at 1000 and $1100 \mathrm{~m}$ possess species characteristic of cerrado sensu stricto and rupestrian grassland, with the presence of rocky outcrops (Mota et al. 2017). 
In addition to E. inflexa, five species of Rhynchospora were common in the seven studied areas. Species of the families Cyperaceae and Poaceae are well represented in rupestrian grasslands (Medina and Fernandes 2007; Rapini et al. 2008; Le Stradic et al. 2015). When comparing the species of the seed bank sampled in our study with the species sampled by Le Stradic et al. (2015) in areas also in Serra do Cipó, it is noted that 24 identified species of the seed bank are present in established vegetation. Of these species, $79 \%$ are species of Cyperaceae and Poaceae. Le Stradic et al. (2015) found Lagenocarpus tenuifolius on stony substrates, Panicum cyanescens and Paspalum hyalinum on sandy substrates and Tatianyx anarctes and Homolepis longispicula on both substrate types. The presence of vegetation species established in the seed bank reflects the regenerative potential of the rupestrian fields of Serra do Cipó.

Does soil influence the composition and distribution of seed bank species along the elevation gradient?

Soil influences the composition and distribution of seed bank species and, among the edaphic variables analyzed, the most important were effective cation exchange capacity $(\mathrm{t}), \mathrm{H}+\mathrm{Al}$, organic matter $(\mathrm{OM})$, base saturation $(\mathrm{V})$, fine sand (FS) and clay. Considering these edaphic variables, which were related to the seed bank, only $\mathrm{V}$ was important in the distribution of regenerating woody vegetation (Mota et al. 2016), and $\mathrm{H}+\mathrm{Al}, \mathrm{OM}$ and $\mathrm{V}$ in the distribution of adult woody vegetation (Mota et al. 2017) in the studied elevation gradient. Furthermore, differences were observed among areas in the edaphic variables of the soil as a result of the gradient analyzed. The areas at intermediate and high elevations possessed more acidic soils, with greater aluminum saturation. Although this high concentration of aluminum is harmful to plants, because 
at low $\mathrm{pH}$, phosphorus, which is a critical element in vegetation development (Sarmiento 1984), can precipitate with aluminum and make it less available to plants (Le Stradic et al. 2015), rupestrian grasslands species are adapted to this conditions.

Intermediate areas, such as 1000 and $1200 \mathrm{~m}$, have high cation exchange capacity (t), which favors nutrient assimilation (Conceição and Pirani 2005), influencing seeds richness at $1000 \mathrm{~m}$ and seed richness and abundance at $1200 \mathrm{~m}$. This edaphic variable represents the capacity of gradually liberation of several nutrients of the soil, favoring the maintenance of its fertility for an extended period of time (Ronquim 2010). As with the soils of the area at $1100 \mathrm{~m}$, some of the plots at 800 and $900 \mathrm{~m}$ have low cation exchange capacity, and these soils must have the capacity to retain cations in reduced exchangeable form. On the other hand, OM was important in the areas at 1100 and $1300 \mathrm{~m}$ (in the selection of models). Organic matter plays a significant role in nutrient recycling, buffering the soil from abrupt changes in $\mathrm{pH}$, construction and maintenance of its structure and adsorption and storage of water, as well as increasing cation exchange capacity (Vargas and Hungria 1997). Areas with low OM content, such as observed at $800 \mathrm{~m}$ (in the CCA), usually possess sandy soils with a low capacity for effective cation exchange. Therefore, these soils possess a low buffering capacity and a high potential for base leaching, besides possible sulfur and micronutrient deficiency (Tomé Junior 1997).

The base saturation (V) is also indicative of soil fertility. According to the saturation percentage described by Ronquim (2010), the soils of the studied areas are considered to have low fertility, which is in agreement with other studies in rupestrian grasslands (Benites et al. 2003; Negreiros et al. 2008; Schaefer et al. 2016). The seed bank was related to $\mathrm{V}$ in all plots in the area at $1300 \mathrm{~m}$ and some of the plots in the area at $1400 \mathrm{~m}$. It was also an important edaphic variable in the variation in seed bank 
abundance in the area at $1200 \mathrm{~m}$. Areas located at the highest elevations, such as 1300 $\mathrm{m}$, also had a strong relationship with clay, which occurred in smaller proportions in the soils of these areas compared to the higher levels in the soils of lower areas. Clay also influenced seed bank richness and abundance of the area at $1100 \mathrm{~m}$. Clay provides greater nutrient retention capacity (Raven et al. 2001; Le Stradic et al. 2015) and has an important ecological role in increasing soil fertility (Conceição and Pirani 2005). Another important physical variable is the proportion of fine sand, which was particularly important in the area at $1200 \mathrm{~m}$ (in the CCA), indicating that the predominant texture of these soils is sandy. Sandy soils are, generally, highly susceptible to erosion and, due to the presence of large pores, can not retain water, which causes excessive drainage and nutrient leaching (Prado 1995). Sandy soils also have low cation exchange capacity, which is almost exclusively of organic matter (Tomé Junior 1997). In the spatial stratified heterogeneity analysis base saturation, coarse sand, clay, fine sand and silt presented greater $q$-values $(0.69,0.67,0.66,0.64$, 0.55 , respectively); since 0 indicates no spatial stratified heterogeneity and 1 indicates perfect spatial stratified heterogeneity (Wang et al. 2016). We can note that physical variables and base saturation may be the most important factors to determine species turnover and $\beta$ diversity.

High levels of $\mathrm{H}+\mathrm{Al}$ usually occur in soils rich in organic matter and that have very low pH (Tomé Júnior 1997), such as the soils of the areas at 1200 and $1400 \mathrm{~m}$, which possessed low $\mathrm{pH}$ and high $\mathrm{H}+\mathrm{Al}$ and organic matter. Thus, the observed results show the complexity and heterogeneity of the sampled areas, where each area possesses different important edaphic variables that affect the richness, abundance, and composition of the seed bank. The richness and abundance of the seed bank was influenced mainly by $\mathrm{t}$ in the lower areas, negatively by the clay in the higher areas, 
positively by the fine sand and $\mathrm{H}+\mathrm{Al}$ in the higher and intermediate areas and negatively by the OM in the lower areas. In addition, in the gradient evaluated (800$1400 \mathrm{~m}$ ) in Serra do Cipó, some species found in this study were characteristic of a certain areas, such as Cyperus sp.2, Schizachyrium sp.2 and Borreria sp.2, at $800 \mathrm{~m}$; Lychnophora pinaster, Lagenocarpus tenuifolius, Diplusodon orbicularis and Marcetia taxifolia, at 900 m; Rhynchospora recurvata, Stylosanthes sp. and Turnera sp.2 at 1000 m; Ageratum fastigiatum, Lagenocarpus rigidus and Panicum sp. at 1100 m; Bulbostylis cf. conifera, Tibouchina heteromala, Trembleya lanifolia, Trachypogon spicatus at 1200 m; Schizachyrium sp.3, Croton sp.1, Mimosa sp. and Miconia sp.2 at 1300 m; and Xyris sp., Schizachyrium cf. sanguineum and Tatyanix anarcites at $1400 \mathrm{~m}$. These species vary in their occurrence and abundance in the seed bank along the elevation gradient and may be indicative of the environmental variation at each area localized in a elevation different. Thus, there is vast biological complexity in this environment, which was attested to by the studies of the aboveground vegetation (Mota et al. 2016, 2017) and verified by the present study.

The analyses presented here show that seed bank of Serra do Cipó does not show a linear pattern of increase or decrease in richness and abundance with elevation, and that the soil, although extremely poor in nutrients, acid and thin in some places, is largely responsible for the high $\beta$ diversity and changes in richness, abundance and composition between areas. In addition, soil attributes of the areas contribute to the low similarity between the areas. The high $\beta$ diversity, the predominance of species turnover in the studied gradient and the low similarity among areas reflect the high species richness in this ecosystem of great environmental heterogeneity. Understanding the factors that influence the seed banks in response to changes in soil, elevation and, 
consequently, climatic conditions, expands our knowledge about high elevation vegetation, especially that of rupestrian grasslands.

\section{Acknowledgments}

We would like to thank the two anonymous reviewers and A. Teixido, T. Bahia and Y. Oki for reviewing earlier versions of the manuscript; D. Negreiros (Centro Universitário UNA), S. Le Stradic (Universidade Estadual Paulista), R. C. Oliveira (Universidade de Brasilia) and S. D'Angelo Neto (Unimontes) for species identification; M. Henrique for the preparation of the map of the study area; and O. Neto and A. Viana for their guidance with statistical analysis. This research was funded by $\mathrm{CNPq}$ (Conselho Nacional de Desenvolvimento Científico e Tecnológico/ PELD-CRSC Site 17), FAPEMIG (Fundação de Amparo à Pesquisa do Estado de Minas Gerais) and CAPES (Coordenação de Aperfeiçoamento de Pessoal de Nível Superior), and supported by Unimontes, Vellozia Reserve, Serra do Cipó National Park, Serra Morena Pousada, Pouso Pedra do Elefante and Textile Industry Cedro. We also thank the field assistance provided by the staff of the Laboratório de Ecologia Vegetal of Unimontes.

\section{References}

Aiba, S., and Kitayama, K. 1999. Structure, composition and species diversity in an altitude-substrate matrix of rain forest tree communities on Mount Kinabalu, Borneo. Plant Ecol. 140(2): 139-157. doi: org/10.1023/A:1009710618040.

APG IV. 2016. An update of the Angiosperm Phylogeny Group classification for the orders and families of flowering plants: APG IV. Bot. J. Linn. Soc. 181(1): 1-20. doi: 10.1111/boj. 12385 . 
Ardissone, R.E. 2014. Sinopse taxonômica de Bulbostylis Kunth (Cyperaceae) para a região Sul do Brasil. M.Sc. Dissertation, Department of Botany, Federal University of Santa Catarina. Florianópolis, Santa Catarina.

Barbosa, N.P.U., Fernandes, G.W., Carneiro, M.A.A., and Junior, L.A.C. 2010. Distribution of non-native invasive species and soil properties in proximity to paved roads and unpaved roads in a quartzitic mountainous grassland of southeastern Brazil (rupestrian fields). Biol. Invasions, 12: 3745-3755. doi 10.1007/s10530-010-9767-y

Barton, K. 2016. Multi-Moldel Interence - Package "MuMin”. R Package Version 1.15.6. Available from https://cran.r-project.org/package=MuMIn [accessed 14 March 2017].

Baselga, A. 2010. Partitioning the turnover and nestedness of beta diversity. Global Ecol. Biogeogr. 19(1): 134-143. doi: 10.1111/j.1466-8238.2009.00490.

Baselga, A., and Orme, C.D.L. 2012. Betapart: an R package for the study of beta diversity. Methods Ecol. Evol. 3(5): 808-812. doi: 10.1111/j.2041-210X.2012.00224.

Beck, J., Holloway, J.D., Khen, C.V., and Kitching, I.J. 2012. Diversity partitioning confirms the importance of beta components in tropical rainforest Lepidoptera. Am. Nat. 180(3): 64-74. doi: 10.1086/666982.

Benites, V.M., Schaefer, C.E.R.G., Mendonça, E.S., and Martin Neto, L. 2001. Caracterização da matéria orgânica e micromorfologia de solos sob Campos de Altitude no Parque Estadual da Serra do Brigadeiro. R. Bras. Ci. Solo, 25(3): 661-674. doi: 10.1590/SO100- 06832001000300015.

Benites, V.M., Caiafa, A.N., Mendonça, E.S., Schaefer, C.E., and Ker, J.C. 2003. Solos e vegetação nos complexos rupestres de altitude da Mantiqueira e do Espinhaço. $\begin{array}{lllll}\text { Floresta } & \text { Ambient. } & \text { 10(1): } & \text { 76-85. } & \text { Available }\end{array}$ http://www.floram.org/files/v10n1/v10n1a8.pdf [accessed 28 June 2017]. 
Benites, V.M., Schaefer, C.E.R., Simas, F.N.B., and Santos, H.G. 2007. Soil associated with rock outcrops in the Brazilian mountain ranges Mantiqueira and Espinhaço. Rev. Bras. Bot. 30(4): 569-577. Available from http://dx.doi.org/10.1590/S0100$\underline{84042007000400003}$ [accessed 02 November 2017].

Bitencourt, C., Rapini, A., Damascena, L.S., and Marco Junior, P. 2016. The worrying future of the endemic flora of a tropical mountain range under climate change. Flora, 218: 1-10. doi: 10.1016/j.flora.2015.11.001.

Borges, R.A.X., Carneiro, M.A.A., and Viana, P.L. 2011. Altitudinal distribution and species richness of herbaceous plants in campos rupestres of Southern Espinhaço Range, Minas Gerais, Brazil. Rodriguesia, 62(1): 139-152. Available from http://rodriguesia-seer.jbrj.gov.br/index.php/rodriguesia/article/view/232/53 [accessed 02 November 2017].

Brown, D. 1992. Estimating the composition of a forest seed bank: a comparison of the seed extraction and seedling emergence methods. Can. J. Bot. 70(8): 1603-1612. doi: 10.1139/b92-202.

Burnham, K.P., Anderson D.R., and Huyvaert K.P. 2011. AIC model selection and multimodel inference in behavioral ecology: some background, observations, and comparisons. Behav. Ecol. Sociobiol. 65(1): 23-35. doi: 10.1007/s00265-010-1084-z. Cain, M.L., Bowman, W.D., and Hacker, S.D. 2001. Ecologia. Artmed, Porto Alegre. Callaway, R.M., Brooker, R.W., Choler, P., Kikvidze, Z., Lortie, C.J., Michalet, R., Paolini, L., Pugnaire, F.I., Newlngham, B., Aschehoug, E.T., Armas, C., and Cook, B. J. 2002. Positive interactions among alpine plants increase with stress. Nature, 417: 844848. doi: $10.1038 /$ nature00812. 
Carmo, F.M.S., Poeiras, L.M., Gonçalves, A.B., Mello, S.M., Meira Neto, J.A.A., Borges, E.E.L., and Silva, A.F. 2012. Germinação do banco de sementes de espécies nativas sob dossel de espécies exóticas. Rev. Árvore, 36(4): 583-591. doi: 10.1590/S0100-67622012000400001.

Carvalho, F., Souza, F.A., Carrenho, R., Moreira, F.M.S., Jesus, E.C., and Fernandes, G.W. 2012. The mosaico f habitats in the high-altitude Brazilian rupestrian fields in a hotspot for arbuscular mycorrhizal fungi. Appl. Soil. Ecol. 52: 9-19. doi: 10.1016/j.apsoil.2011.10.001.

Conceição, A.A., and Pirani, J.R. 2005. Delimitação de habitats em campos rupestres na Chapada Diamantina, Bahia: substratos, composição florística e aspectos estruturais. Bol. Bot. Univ. São Paulo 23(1): 85-111. Available from http://www.jstor.org/stable/42871672 [accessed 21 April 2017].

Conceição, A.A., and Pirani, J.R. 2007. Diversidade em quatro áreas de campos rupestres na Chapada Diamantina, Bahia, Brasil: espécies distintas, mais riquezas similares. $\quad$ Rodriguesia, $\quad$ 58(1): 193-206. Available from https://rodriguesia.jbrj.gov.br/FASCICULOS/rodrig58 1/014-017-06.pdf [accessed 21 April 2017].

Crawley, M.J. 2002. Statistical computing: an introduction to data analysis using SPlus. Wiley, Chichester.

Crawley, M.J. 2013. The R Book. John Wiley and Sons Ltd, Chichester.

Cummins, R.P., and Miller, G.R. 2002. Altitudinal gradients in seed dynamics of Calluna vulgaris in eastern Scotland. J. Veg. Sci. 13(6): 859-866. doi: 10.1111/j.16541103.2002.tb02115.

Embrapa. 1997. Centro Nacional de Pesquisa de Solos. Manual de métodos de análise de solos. Embrapa-CNPS, Rio de Janeiro. 
Fernandes, G.W. 1992. A gradient analysis of plant forms from Northern Arizona. J. Ariz.-Nev. Acad. Sci. 24/25: 21-30. Available from http://www.jstor.org/stable/40021291 [accessed 10 April 2017].

Fernandes, G.W., Barbosa, N.U., Negreiros, D., and Paglia, A.P. 2014. Challenges for the conservation of vanishing megadiverse rupestrian grasslands. Nat. Conserv. 12(2): 162-165. doi: 10.1016/j.ncon.2014.08.003.

Fernandes, G.W., Almeida, H.A., Nunes, C.A., Xavier, J.H.A., Coob, N.S., Carneiro, M.A.A., Cornelissen, T., Neves, F.S., Ribeiro, S.P., Nunes, Y.R.F., Pires, A.C.V., and Beirão, M.V. 2016. Cerrado to rupestrian grasslands: patterns of species distribution and the forces shaping them along an altitudinal gradient. In Ecology and conservation of mountain-top grasslands in Brazil. Edited by G.W. Fernandes. Springer International, Cham, Baviera. pp. 345-371.

Funes, G., Basconcelo, S., Díaz, S., and Cabido, M. 2003. Seed bank dynamics in talltussock grasslands along an altitudinal gradient. J. Veg. Sci. 14(2): 253-258. doi: 10.1111/j.1654-1103.2003.tb02150.

Garwood, N.C. 1989. Tropical soil seed banks: a review. In Ecology of Soil Seed Banks. Edited by M.A. Leck, V.T. Parker, and R.L. Simpson. Academic Press, San Diego, CA. pp. 149-209.

Gentry, A.H. 1988. Changes in plant community diversity and floristic composition on environmental and geographical gradients. Ann. Mo. Bot. Gard. 75(1): 1-34. doi: $10.2307 / 2399464$.

Giulietti, A.M., Menezes, N.L., Pirani, J.R., Meguro, M., and Wanderley, M.G.L. 1987. Flora da Serra do Cipó, Minas Gerais: caracterização e lista das espécies. Bol. Bot. 9: 1151. Available from http://www.revistas.usp.br/bolbot/article/viewFile/57726/60779 [accessed 02 November 2017]. 
Gulshan, A.B., and Dasti, A.A. 2012. Role of soil texture and depths on the emergence of buried weed seeds. ARPN J. Agric. Biol. Sci. 7(4): 223-228. Available from http://www.arpnjournals.com/jabs/research_papers/rp_2012/jabs_0412_381.pdf. [accessed 02 November 2017].

Hamilton, A. 1975. A quantitative analysis of altitudinal zonation in Uganda forests. Vegetatio, 30(2): 99-106. doi: 10.1007/BF02389611.

Hammer, O. 2012. PAST: Paleontological statistic, Version 2.16. Manual de referência. University of Oslo, Oslo.

Howe, H.F., and Smallwood, J. 1982. Ecology of seed dispersal. Annu. Rev. Ecol Syst. 13: 201-228. Available from https://doi.org/10.1146/annurev.es.13.110182.001221 [accessed 01 November 2017].

Hussain, M.Z., and Malik, N.Z. 2012. High altitude forest composition diversity and its component in a part of Ganga Chotti and Bedori Hills District Bagh. Azad Jammu and Kashmir, Pakistan. AGD Lands Environ. 6(1): 31-40. Available from http://citeseerx.ist.psu.edu/viewdoc/download?doi=10.1.1.388.6183\&rep=rep1\&type=p df. [accessed 01 November 2017].

Joly, C.A., Assis, M.A., Bernacci, L.C., Tamashiro, J.Y., Campos, M.C.R., Gomes J.A.M.A., Lacerda, M.S., Santos, F.A.M., Pedroni, F., Pereira, L.S., Padgurschi, G., Prata, E.M.B., Ramos, E., Torres, R.B., Rochelle, A., Martins, F.R., Alves, L.F., Vieira, S.A., Martinelli, L.A., Camargo, P.B., Aidar, M.P.M., Eisenlohr, E.S., Villani, J.P., and Belinello, R. 2012. Florística e fitossociologia em parcelas permanentes da Mata Atlântica do sudeste do Brasil ao longo de um gradiente altitudinal. Biota Neotrop. 12(1): 125-145. doi: 10.1590/S1676-06032012000100012.

Kharkwal, G., Mehrotra, P., Rawat, Y.S., and Pangtey, Y.P.S. 2005. Phytodiversity and growth form in relation to altitudinal gradient in the Central Himalayan (Kumaun) 
region of India. Curr. Sci. 89(5): 873-887. Available from http://www.iisc.ernet.in/currsci/sep102005/873.pdf [accessed 12 January 2017].

Kitayama, K. 1992. An altitudinal transect study of the vegetation on Mount Kinabalu, Borneo. $\quad$ 102(2): 149-171. Avetatio, Available from https://link.springer.com/article/10.1007/BF00044731. [accessed 01 November 2017]. Le Stradic S. 2012. Composition, phenology and restoration of campo rupestre mountain grasslands - Brazil. PhD. Thesis, Universite' d'Avignon et des Pays de Vaucluse, Avignon and Federal University of Minas Gerais, Belo Horizonte, Minas Gerais.

Le Stradic, S., Buisson, E., and Fernandes, G.W. 2015. Vegetation composition and structure of some Neotropical mountain grasslands in Brazil. J. Mt. Sci. 12(4): 864-877. doi: 10.1007/s11629-013-2866-3.

Lieberman D., Lieberman, M., Peralta, R., and Hartshorn, G.S. 1996. Tropical forest structure and composition on a large-scale altitudinal gradient in Costa Rica. J. Ecol. 84(2): 137-152. doi: $10.2307 / 2261350$.

Lippok, D., Walter, F., Hensen, I., Beck, S., and Schleuning, M. 2013. Effects of disturbance and altitude on soil seed banks of tropical montane forests. J. Trop. Ecol. 29(6): 523-529. doi: 10.1017/S0266467413000667.

Lomolino, V.M. 2001. Elevation gradients of species-density: historical and prospective view. Glob. Ecol. Biogeogr. 10(1): 3-13. doi: 10.1046/j.1466-822x.2001.00229.x.

Ma, M., Zhou, X., Wang, G., Ma, Z., and Du, G., 2010. Seasonal dynamics in alpine meadow seed banks along an altitudinal gradient on the Tibetan Plateau. Plant Soil, 336(1-2): 291-302. doi: 10.1007/s11104-010-0480-5.

Madeira J.A., and Fernandes G.W., 1999. Reproductive phenology of sympatric taxa of Chamaecrista (Leguminosae) in Serra do Cipó. Brazil. J. Trop. Ecol. 15(4): 463-479. 
Available from https://www.cambridge.org/core/journals/journal-of-tropicalecology/article/reproductive-phenology-of-sympatric-taxa-of-chamaecristaleguminosae-in-serra-do-cipo-brazil/4295CCCCA4542958BABB8E51C533E4D1 [accessed 8 February 2017]. Magnago, L.F., Magrach, A., Laurance, W., Martins, S.V., Meira-Neto, J.A., Simonelli, M., and Edwards, D.P. 2015. Would protecting tropical forest fragments provide carbono and biodiversity cobenefits under REDD+? Global Change Biol. 21(9): 34553468. doi: $10.1111 / \mathrm{gcb} .12937$.

Marques, T., and Schoereder, J.H. 2013. Ant diversity partitioning across spatial scales: ecological processes and implications for conserving Tropical Dry Forests. Austral Ecol. 39(1): 72-82. doi: 10.1111/aec.12046.

McCune, B., and Mefford, M.J. 2011. PC-ORD: Multivariate analysis of ecological data. Version 6. MjM Software, Gleneden Beach, Oregon.

Medina, B.M.O., and Fernandes, G.W. 2007. The potential of natural regeneration of rocky outcrop vegetation on rupestrian fields soils in "Serra do Cipó”, Brazil. Rev. Bras. Bot. 30(4): 665-678. doi: 10.1590/S0100-84042007000400011.

Mota, N.M., Rezende, V.L., Mota, G.S., Fernandes, G.W., and Nunes, Y.R.F. 2016. Forces driving the regeneration component of a rupestrian grassland complex along an altitudinal gradient. Braz. J. Bot. 39(3): 845-860. doi: 10.1007/s40415-016-0287-6. Mota, G.S., Luz, G. R., Mota, N.M., Coutinho, E.S., Veloso, M.D.M., Fernandes, G.W., and Nunes, Y.R.F. 2017. Changes in species composition, vegetation structure, and life forms along an altitudinal gradient of rupestrian grasslands in Southeastern Brazil. Flora, 51107. doi: http://dx.doi.org/10.1016/j.flora.2017.03.010.

Muggeo, V. 2008. Segmented: an R package to fit regression models with broken-line $\begin{array}{llllll}\text { relationships. } & \mathrm{R} & \text { News } & \mathbf{8}(1) & \text { 20-25. } & \text { Available from }\end{array}$ 
https://www.researchgate.net/publication/234092680_Segmented_An R Package to F it_Regression_Models_With_Broken-Line_Relationships [accessed 20 February 2017]. Murdoch, A.J., and Ellis, R.H. 1992. Longevity, viability and dormancy. In Ecology of soil seed banks. Edited by M.A. Leck, V.T. Parker, and R.L. Simpson. Academic Press, San Diego, CA. pp. 193-229.

Negreiros, D., Moraes, M.L.B., and Fernandes, G.W. 2008. Caracterização da fertilidade dos solos de quatro leguminosas de campos rupestres, Serra do Cipó, MG, Brasil. J. Soil Sc. Plant Nutr. 8(4): 30-39. doi: 10.4067/S0718-27912008000300003.

Negreiros, D, Fernandes, G.W., Silveira, F.A.O., and Chalub, C. 2009. Seedling growth and biomass allocation of endemic and threatened shrubs of rupestrian fields. Acta Oecol. 35:301-310. doi:10.1016/j.actao.2008.11.006.

Neves, F.S., Queiroz-Dantas, K.S., Rocha, W.D., and Delabie, J.H.C. 2013. Ants of three adjacent habitats of a transition region between the cerrado and caatinga biomes: The Effects of heterogeneity and variation in canopy cover. Neotrop. Entomol. 42(3): 258-268. doi: 10.1007/s13744-013-0123-7.

Nunes, C.A., Braga, R.F., Figueira, J.E.C., Neves, F.S., and Fernandes, G.W. $2016 a$. Dung beetles along a tropical altitudinal gradient: environmental filtering on taxonomic and functional diversity. Plos One, 11(6): e0157442. doi: 10.1371/journal.pone.0157442.

Nunes, F.P., Dayrell, R.L.C., Silveira, F.A.O., Negreiros, D., Santana, D.G., Carvalho, F.J., Garcia, Q.S., and Fernandes, G.W. 2016b. Seed germination ecology in rupestrian grasslands. In Ecology and conservation of mountain-top grasslands in Brazil. Edited by G.W. Fernandes. Springer International, Cham, Baviera. pp. 207-226. 
Oke, S.O., and Okunola, K.A. 2008. Seed bank dynamics in altitudinal gradient on an inselberg in a Nigerian secondary forest. Res. J. Environ. Sci. 2(2): 81-90. doi: 10.3923/rjes.2008.81.90.

Oksanen, J., Blanchet, F.G., Friendly, M., Kindt, R., Legendre, P., McGlinn, D., Minchin, P.R., O'Hara, R.B., Simpson, G.L., Solymos, P., Stevens, M.H.H., Szoecs, E., and Wagner, H. 2017. Vegan: community ecology package. Available from http://CRAN.R-project.org/package=vegan [accessed 15 May 2017].

Ortega, C., Levassor, C., and Peco, B. 1997. Seasonal dynamics of Mediterranean pasture seed banks along environmental gradientes. J. Biogeogr. 24(2): 177-195. doi: 10.1046/j.1365-2699.1997.00080.x

Pereira, I.M., Alvarenga, A.P., and Botelho, S.A. 2010. Banco de sementes do solo, como subsídio a recomposição de mata ciliar. Floresta, 40(4): 721-730. Available from http://revistas.ufpr.br/floresta/article/view/20324/13482 [accessed 19 May 2017].

Prado, H. 1995. A pedologia simplificada. Arquivo do Agrônomo. Potafos, São Paulo.

R Core Team. 2015. $R$ : A language and environment for statistical computing. $\mathrm{R}$ Foundation for Statistical Computing, Vienna, Austria. Available from http://www.Rproject.org/ [accessed 19 May 2017].

Rapini, A., Ribeiro, P.L., Lambert, S., and Pirani, J.R., 2008. A flora dos campos rupestres da Cadeia do Espinhaço. Megadiversidade, 4(1-2): 16-24. Available from http://www.inot.org.br/artigo/Rapini_et_al_2008_A_flora_dos_campos_rupestres_da_C adeia_do_Espinhaco.pdf [accessed 21 June 2017].

Raven, P.H., Evert, R.F., and Eichhorn, S.E. 2001. Biologia vegetal. Guanabara Koogan, Rio de Janeiro.

Ripley, B., Venables, B., Hornik, K., Gebjardt, A., and Firth, D. 2017. Support Functions and Datasets for Venables and Ripley's MASS. Package MASS. Available 
from https://cran.r-project.org/web/packages/MASS/MASS.pdf [accessed 23 May 2017].

Ronquim, C.C. 2010. Conceitos de fertilidade do solo e manejo adequado para as regiões tropicais. Boletim de Pesquisa e Desenvolvimento. Embrapa Monitoramento por Satélite, Campinas.

Sang W. 2009. Plant diversity patterns and their relationships with soil and climatic factors along an altitudinal gradient in the middle Tianshan Mountain area, Xinjiang, China. Ecol. Res. 24(2): 303-314. Available from https://link.springer.com/article/10.1007\%2Fs11284-008-0507-z [accessed 24 March 2017].

Sarmiento, G. 1984. The ecology of Neotropical Savannas. Harvard University Press, Cambridge.

Shaefer, C.E.G.R., Corrêa, G.R., Candido, H.G., Arruda, D.M., Nunes, J.A., Araújo, R.W., Rodrigues, P.M.S., and Fernandes Filho, E.I. 2016. The physical environment of rupestrian grasslands (campos rupestres) in Brazil: Geological, geomorphological and pedological characteristics and interplays. In Ecology and conservation of mountain-top grasslands in Brazil. Edited by G.W. Fernandes. Springer International, Cham, Baviera. pp. 15-54.

Shaheen, H., Mashwani, Z.U.R., and Dar, M.E.U.I. 2015. Spatial patterns and diversity of alpine vegetation across Langer-Shandur Valley, Hindukush Himalayas. Curr. Sci. 108(8): 1534-1539. Available from http://www.currentscience.ac.in/Volumes/108/08/1534.pdf. [accessed 01 November 2017].

Sharma, C.M., Suyal, S., Gaiorola, S., and Ghildiyal, S.K. 2009. Species richness and diversity along an altititudinal gradient moist temperate forest of Garhwal Himalaya. J. 
$\begin{array}{lllll}\text { Am. } & \text { Sci. } & \text { 5(5): } & \text { 119-128. } & \text { Available }\end{array}$ http://www.sciencepub.net/american/0505/15 0937_mauscript_am0505.pdf [accessed 18 March 2017].

Spehn E.M, Rudmann-Maurer K., Korner, C., and Maselli, D. 2010. Mountain biodiversity and global change. GMBA-DIVERSITAS, Basel.

Ter Braak, C.J.F. 1987. The analysis of vegetation-environment relationships by canonical correspondence analysis. Vegetatio, 69(1-3): 69-77. doi: 10.1007/BF00038688.

Tester M., and Morris C. 1987. The penetration of light through soil. Plant Cell Environ. 10(4): 281-286. doi: 10.1111/j.1365-3040.1987.tb01607.x

Toledo-Garibaldi, M., and Williams-Linera, G. 2014. Tree diversity patterns in successive vegetation types along an elevation gradient in the Mountains of Eastern Mexico. Ecol. Res. 29(6): 1097-1104. doi: 10.1007/s11284-014-1196-4.

Tomé Júnior, J. B. 1997. Manual para interpretação de análise de solo. Livraria e Editora Agropecuária, Guaíba.

Vargas, M.A.T., and Hungria, M. 1997. Fixação biológica do N2 na cultura da soja. In Biologia dos solos de cerrado. Edited by M.A.T. Vargas and M..Hungria. Empresa Brasileira de Pesquisa Agropecuária, Planaltina. pp. 297-360.

Veech, J.A., Summerville, K.S., Crist, T.O., and Gering, J.C. 2002. The additive partitioning of diversity: recent revival of an old idea. Oikos, 99(1): 3-9. doi: 10.1034/j.1600-0706.2002.990101.x.

Wang, G., Zhou, G., Yang, L., and Li, Z. 2002. Distribution species diversity and lifeform spectra of plant communities along an altitudinal gradient in the northern slopes of Qilianshan Mountains, Gansu, China. Plant Ecol. 165(2): 169-181. doi: 10.1023/A:1022236115186. 
Wang, J.F., Zhang, T.L., and Fu, B.J. 2016. A measure of spatial stratified heterogeneity. Ecol. Indic. 67: 250-256. doi: 10.1016/j.ecolind.2016.02.052.

Whittaker, R.H. 1956. Vegetation of the Great Smoky Mountains. Ecol. Monogr. 26(1): 1-80. doi: $10.2307 / 1943577$.

Williams Linera, G. 1993. Soil seed banks in four lower montane forest of Mexico. J. Trop. Ecol. 9(3): 321-337. Available from http://www.jstor.org/stable/2559532 [accessed 8 July 2017]. 
Table 1. Results of Generalized Linear Models for abundance and richness of the seed bank along an elevation gradient in Serra do Cipó, Minas Gerais, Brazil. Values are degrees of freedom and AICc parameters. One-segmented is the model with one breakpoint.

\begin{tabular}{lccc}
\hline Variables & Model & $d f$ & AICc \\
\hline \multirow{3}{*}{ Richness } & one-segmented & 5 & 497.668 \\
& linear model & 3 & 515.748 \\
& null & 2 & 517.599 \\
Abundance & one-segmented & 5 & 682.893 \\
& linear model & 3 & 728.152 \\
& null & 2 & 726.056 \\
\hline
\end{tabular}


Table 2. Analysis of Variance with Generalized Linear Models and q-statistic values of edaphic variables at the seven elevations studied in Serra

do Cipó, Minas Gerais, Brazil. All variables were significant at $p<0.01$. Abbreviations for edaphic variable are in the text.

\begin{tabular}{|c|c|c|c|c|c|c|c|c|c|}
\hline \multirow{2}{*}{$\begin{array}{l}\text { Edaphic } \\
\text { variable }\end{array}$} & \multicolumn{7}{|c|}{ Altitude (m) } & \multirow[t]{2}{*}{$F$} & \multirow[t]{2}{*}{$q$-estatistic } \\
\hline & 800 & 900 & 1000 & 1100 & 1200 & 1300 & 1400 & & \\
\hline $\mathrm{pH}$ & $5.15 \pm 0.07 \mathrm{a}$ & $5.05 \pm 0.06 \mathrm{a}$ & $5.18 \pm 0.06 a$ & $4.99 \pm 0.05 b$ & $4.80 \pm 0.11 b$ & $4.78 \pm 0.16 b$ & $4.70 \pm 0.08 b$ & 4.278 & 0.23 \\
\hline P-Merlich & $2.91 \pm 0.37 \mathrm{a}$ & $1.16 \pm 0.13 b$ & $1.16 \pm 0.12 b$ & $1.15 \pm 0.08 b$ & $2.70 \pm 0.46 a$ & $1.02 \pm 0.18 b$ & $2.38 \pm 0.33 a$ & 11.313 & 0.40 \\
\hline P-Rem & $32.60 \pm 0.07 b$ & $30.30 \pm 0.06 c$ & $32.81 \pm 0.06 b$ & $29.12 \pm 0.05 c$ & $24.86 \pm 0.11 \mathrm{c}$ & $39.26 \pm 0.15 a$ & $33.90 \pm 0.08 b$ & 44.628 & 0.33 \\
\hline $\mathrm{K}^{+}$ & $49.45 \pm 3.88 \mathrm{a}$ & $31.66 \pm 2.80 b$ & $30.08 \pm 4.90 b$ & $33.06 \pm 2.60 b$ & $41.15 \pm 5.45 a$ & $15.32 \pm 0.64 c$ & $25.06 \pm 3.82 b$ & 67.030 & 0.38 \\
\hline $\mathrm{Ca}^{++}$ & $0.25 \pm 0.02 b$ & $0.20 \pm 0.00 b$ & $0.20 \pm 0.00 b$ & $0.21 \pm 0.01 b$ & $0.21 \pm 0.01 b$ & $0.20 \pm 0.00 b$ & $0.28 \pm 0.03 a$ & 5.318 & 0.25 \\
\hline $\mathrm{Mg}^{++}$ & $0.15 \pm 0.01 \mathrm{a}$ & $0.10 \pm 0.00 \mathrm{~b}$ & $0.10 \pm 0.00 \mathrm{~b}$ & $0.11 \pm 0.01 b$ & $0.10 \pm 0.00 \mathrm{~b}$ & $0.10 \pm 0.00 \mathrm{~b}$ & $0.17 \pm 0.02 \mathrm{a}$ & 13.23 & 0.44 \\
\hline $\mathrm{Al}$ & $1.43 \pm 0.07 b$ & $1.69 \pm 0.20 b$ & $1.62 \pm 0.22 b$ & $1.87 \pm 0.12 b$ & $2.48 \pm 0.24 \mathrm{a}$ & $1.29 \pm 0.111 b$ & $2.66 \pm 0.24 a$ & 7.895 & 0.36 \\
\hline $\mathrm{H}+\mathrm{Al}$ & $1.95 \pm 0.13 b$ & $5.08 \pm 0.70 \mathrm{a}$ & $2.47 \pm 0.36 b$ & $5.87 \pm 0.62 \mathrm{a}$ & $5.86 \pm 0.58 \mathrm{a}$ & $1.99 \pm 0.16 b$ & $5.89 \pm 0.47 a$ & 15.985 & 0.53 \\
\hline SB & $0.53 \pm 0.03 a$ & $0.38 \pm 0.01 b$ & $0.38 \pm 0.01 b$ & $0.40 \pm 0.02 b$ & $0.42 \pm 0.02 b$ & $0.34 \pm 0.00$ & $0.52 \pm 0.04 a$ & 10.893 & 0.42 \\
\hline $\mathrm{t}$ & $1.96 \pm 0.09 a$ & $2.07 \pm 0.21 b$ & $1.99 \pm 0.23 \mathrm{a}$ & $2.27 \pm 0.13 b$ & $2.90 \pm 0.25 b$ & $1.60 \pm 0.11 \mathrm{a}$ & $3.18 \pm 0.25 \mathrm{c}$ & 8.3283 & 0.37 \\
\hline M & $72.64 \pm 1.07 \mathrm{c}$ & $78.67 \pm 2.49 b$ & $79.41 \pm 1.35 b$ & $82.01 \pm 0.76 b$ & $84.04 \pm 1.53 \mathrm{a}$ & $77.57 \pm 1.41 b$ & $82.81 \pm 1.69 b$ & 6.233 & 0.31 \\
\hline $\mathrm{T}$ & $2.48 \pm 0.14 b$ & $5.46 \pm 0.71 \mathrm{a}$ & $2.85 \pm 0.37 b$ & $6.27 \pm 0.64 a$ & $6.28 \pm 0.59 a$ & $2.40 \pm 0.15 b$ & $6.41 \pm 0.47 \mathrm{a}$ & 15.449 & 0.52 \\
\hline V & $21.92 \pm 1.10 \mathrm{a}$ & $8.74 \pm 1.24 c$ & $15.10 \pm 1.24 b$ & $7.04 \pm 0.68 c$ & $7.39 \pm 0.73 c$ & $14.91 \pm 0.80 \mathrm{~b}$ & $8.55 \pm 0.87 c$ & 32.257 & 0.69 \\
\hline $\mathrm{OM}$ & $3.51 \pm 0.17 \mathrm{c}$ & $5.037 \pm 0.48 b$ & $3.57 \pm 0.41 \mathrm{c}$ & $5.59 \pm 0.48 b$ & $6.90 \pm 0.65 a$ & $3.57 \pm 0.19 c$ & $6.90 \pm 0.58 \mathrm{a}$ & 11.201 & 0.44 \\
\hline $\mathrm{CS}$ & $17.84 \pm 1.08 \mathrm{a}$ & $4.18 \pm 0.68 c$ & $17.65 \pm 1.48 \mathrm{a}$ & $4.88 \pm 0.45 c$ & $12.80 \pm 1.09 b$ & $18.17 \pm 1.36 \mathrm{a}$ & $9.35 \pm 1.41 b$ & 28.683 & 0.67 \\
\hline FS & $62.77 \pm 1.01 \mathrm{~d}$ & $72.59 \pm 1.16 b$ & $67.11 \pm 1.66 c$ & $81.12 \pm 1.20 \mathrm{a}$ & $75.66 \pm 0.97 b$ & $73.74 \pm 1.40 b$ & $78.49 \pm 1.26 \mathrm{a}$ & 25.623 & 0.64 \\
\hline Silt & $11.54 \pm 0.68 \mathrm{a}$ & $12.46 \pm 1.20 \mathrm{a}$ & $8.15 \pm 0.77 b$ & $5.54 \pm 0.40 c$ & $6.00 \pm 0.51 c$ & $4.92 \pm 0.43 \mathrm{c}$ & $7.85 \pm 0.57 b$ & 19.23 & 0.55 \\
\hline Clay & $7.85 \pm 0.53 c$ & $10.77 \pm 0.36 \mathrm{a}$ & $7.08 \pm 0.66 d$ & $8.46 \pm 0.79 b$ & $5.54 \pm 0.33 \mathrm{e}$ & $3.08 \pm 0.29 g$ & $4.31 \pm 0.21 \mathrm{f}$ & 30.847 & 0.66 \\
\hline
\end{tabular}


Table 3. Analysis of the results of the canonical correspondence analysis (CCA) of the abundance of 149 seed bank species sampled in 91 plots among seven elevations of rupestrian grasslands in Serra do Cipó, Brazil. The values represent the internal correlations (intraset) between the soil characteristics and the first two ordering axes, and the matrix of weighted correlations between potential soil acidity $(\mathrm{H}+\mathrm{Al})$, effective cation exchange capacity $(\mathrm{t})$, base saturation (V), organic matter (OM), proportions of fine sand (FS), and clay.

\begin{tabular}{|c|c|c|c|c|c|c|c|}
\hline \multirow{2}{*}{$\begin{array}{l}\text { Edaphic } \\
\text { variables }\end{array}$} & \multicolumn{2}{|c|}{ Intraset correlations } & \multicolumn{5}{|c|}{ Edaphic variables } \\
\hline & Eixo 1 & Eixo 2 & $\mathrm{H}+\mathrm{Al}$ & $\mathrm{T}$ & $\mathrm{V}$ & $\mathrm{OM}$ & $\mathrm{FS}$ \\
\hline $\mathrm{H}+\mathrm{Al}$ & -0.052 & -0.772 & & & & & \\
\hline $\mathrm{t}$ & -0.129 & -0.793 & 0.774 & & & & \\
\hline $\mathrm{V}$ & 0.261 & 0.700 & -0.85 & 0.589 & & & \\
\hline OM & 0.089 & -0.970 & 0.799 & -0.784 & -0.678 & & \\
\hline FS & -0.511 & -0.536 & 0.555 & 0.283 & -0.635 & 0.403 & \\
\hline Clay & 0.694 & 0.183 & 0.107 & -0.166 & 0.092 & -0.16 & -0.248 \\
\hline
\end{tabular}




\section{Legends to figures and Appendix}

Figure 1. Geographic location of Serra do Cipó showing the Espinhaço Mountain Range in Minas Gerais, and indicating the sampling sites (800-1400 m).

Figure 2. Species richness (a) and abundance (b) of germinated seeds along an elevation gradient in Serra do Cipó, Brazil, with a breakpoint at $1200 \mathrm{~m}$.

Figure 3. Species richness (a) and abundance (b) of germinated seeds along an altitudinal gradient in Serra do Cipó, Brazil. Values are means $\pm S D(n=13)$. Different letters indicate significant differences $(p \leq 0.05)$ between means.

Figure 4. Additive diversity partitioning for the seed bank of an elevation gradient in Serra do Cipó, Brazil. The component $\alpha$ represents the percent of the number of germinated species per plot; $\beta 1$ represents $\beta$ diversity due to the percent of species among plots; $\beta 2$ represents the percent of species among different areas. Observed values were compared statistically with expected values (* means $p<0.001)$.

Figure 5. Diagram of nonparametric multidimensional scaling (nMDS) of the species of the seed bank at seven elevations $(800-1400 \mathrm{~m})$ in the rupestrian grasslands of Serra do Cipó, Brazil.

Figure 6. Canonical correspondence analyses (CCA): plot ordination diagrams (A) and seed bank species (B) based on the distribution of the number of individuals of 30 species with 10 or more individuals in 91 plots among seven elevations in rupestrian 
grasslands in Serra do Cipó, Brazil, and its correlation with soil variables: OM, t, V, H + Al, FS and clay.

Table A1. Germinated species, their respective families, voucher and occurrence in each area in the evaluated elevation gradient $(800-1400 \mathrm{~m})$ in Serra do Cipó, Southeastern Brazil. 


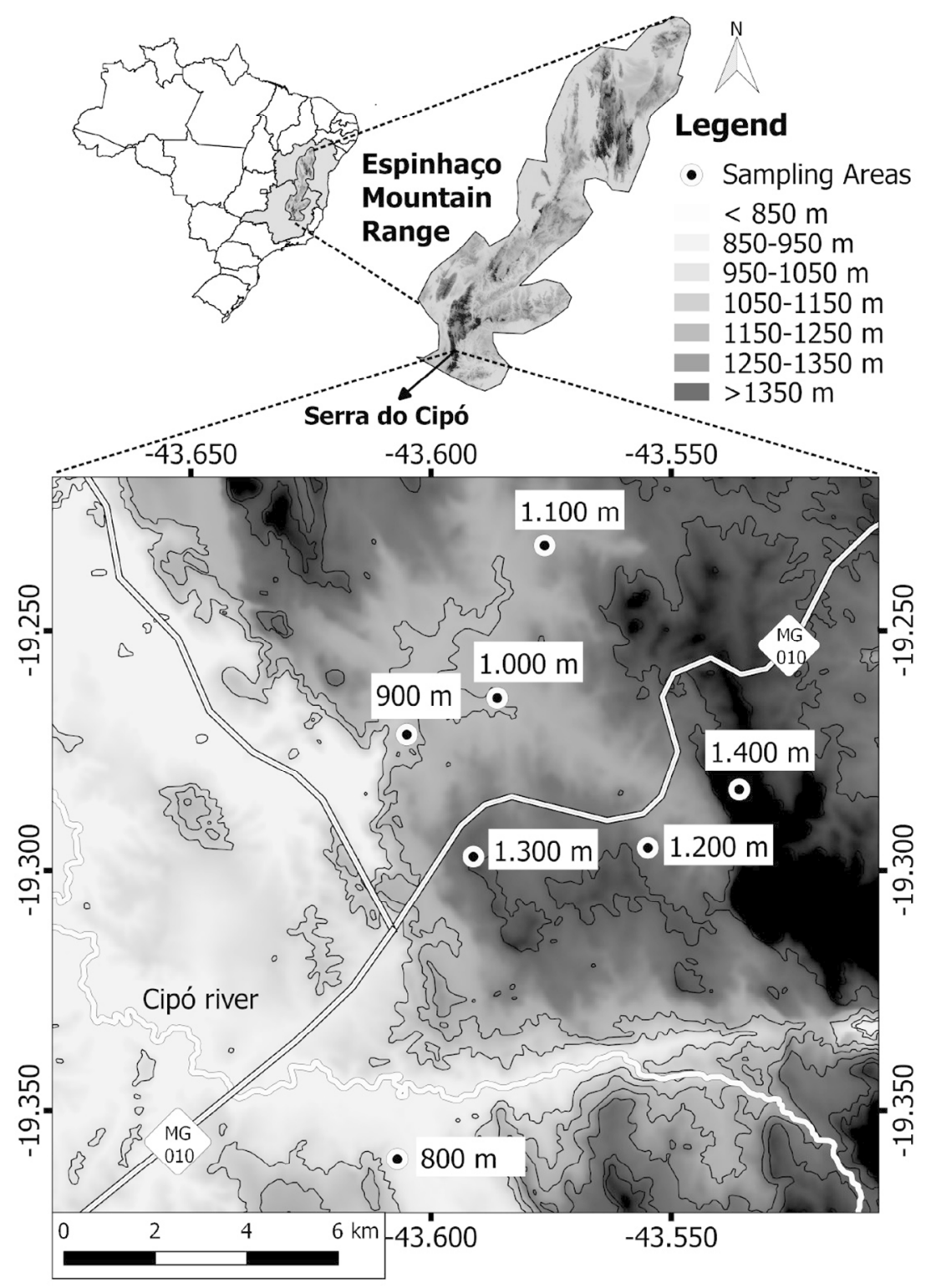

Figure 1. Geographic location of Serra do Cipó showing the Espinhaço Mountain Range in Minas Gerais, and indicating the sampling sites $(800-1400 \mathrm{~m})$.

$95 \times 135 \mathrm{~mm}(300 \times 300 \mathrm{DPI})$ 


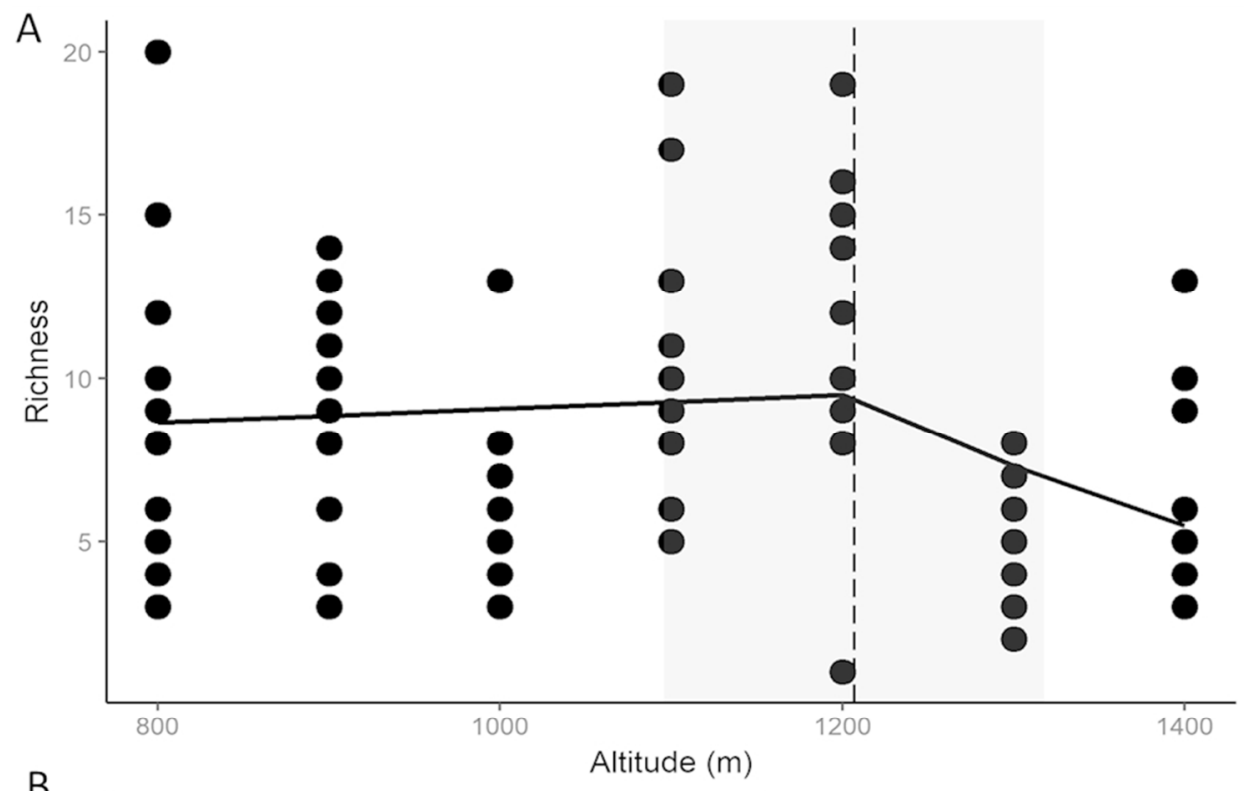

B

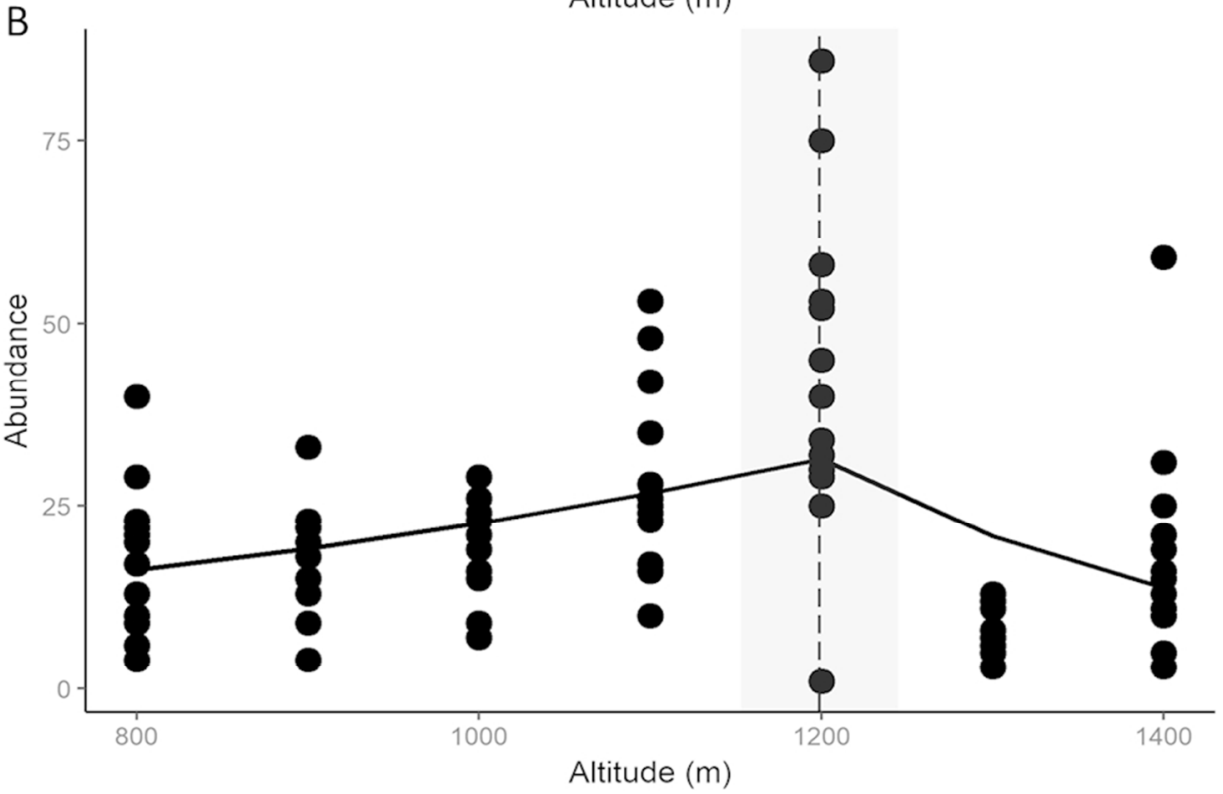

Figure 2. Species richness (a) and abundance (b) of germinated seeds along an elevation gradient in Serra do Cipó, Brazil, with a breakpoint at $1200 \mathrm{~m}$.

$87 \times 110 \mathrm{~mm}(300 \times 300 \mathrm{DPI})$ 
A

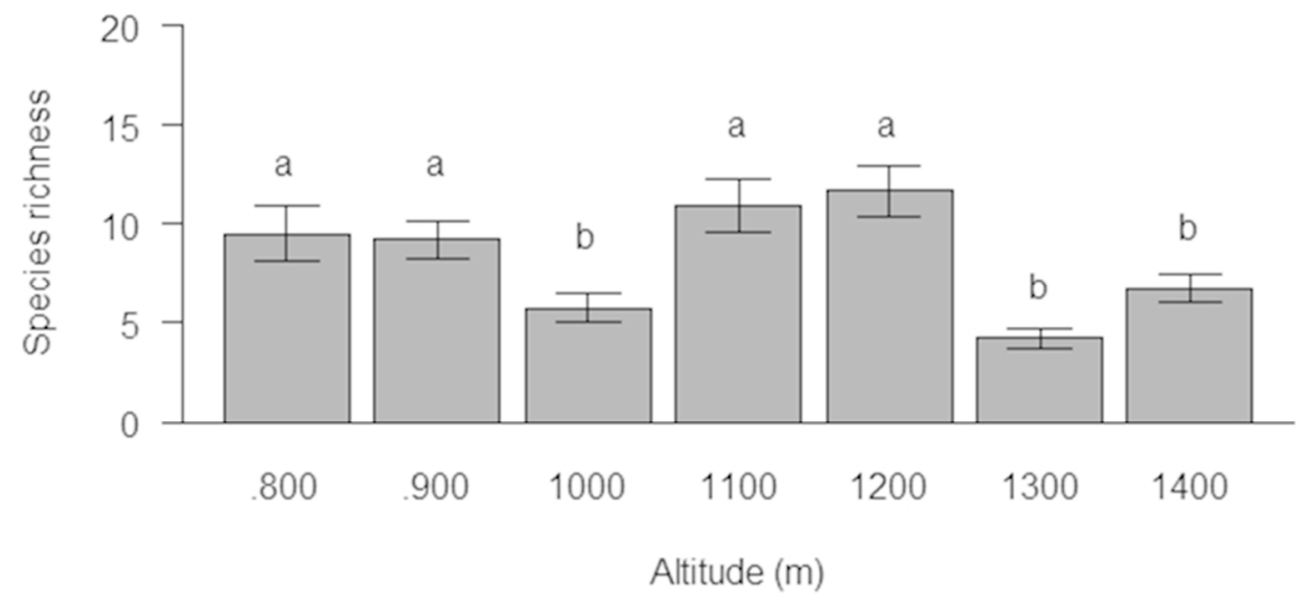

B

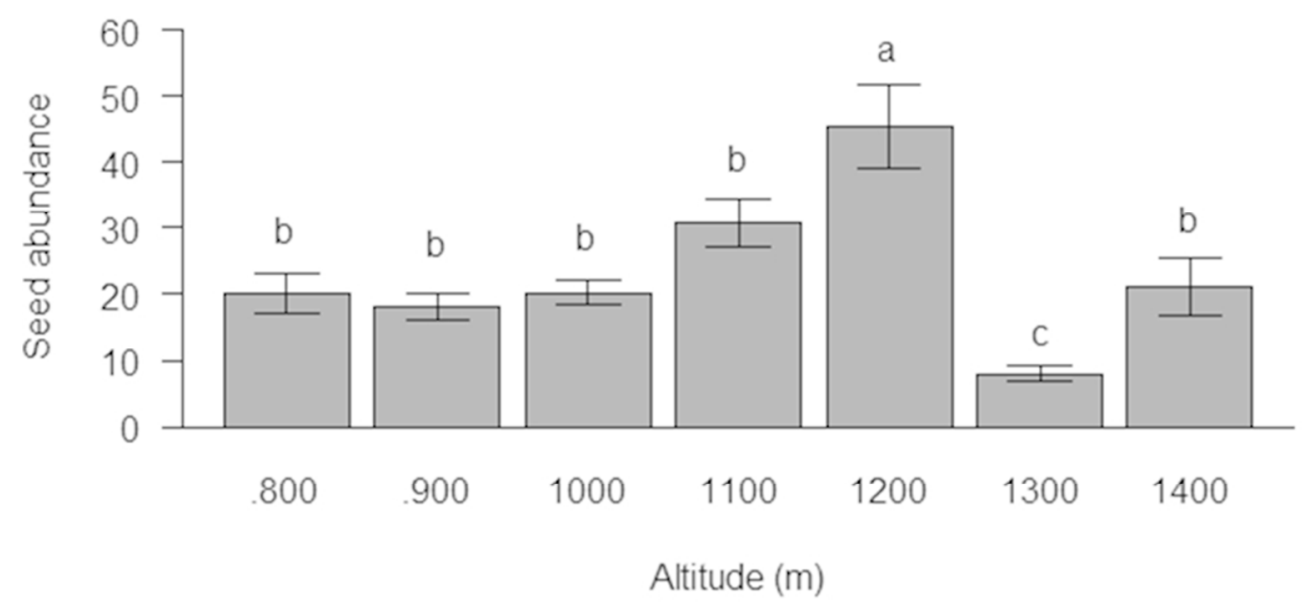

Figure 3. Species richness (a) and abundance (b) of germinated seeds along an altitudinal gradient in Serra do Cipó, Brazil. Values are means \pm SD $(n=13)$. Different letters indicate significant differences $(p \leq 0.05)$ between means.

$78 \times 89 \mathrm{~mm}(300 \times 300 \mathrm{DPI})$ 


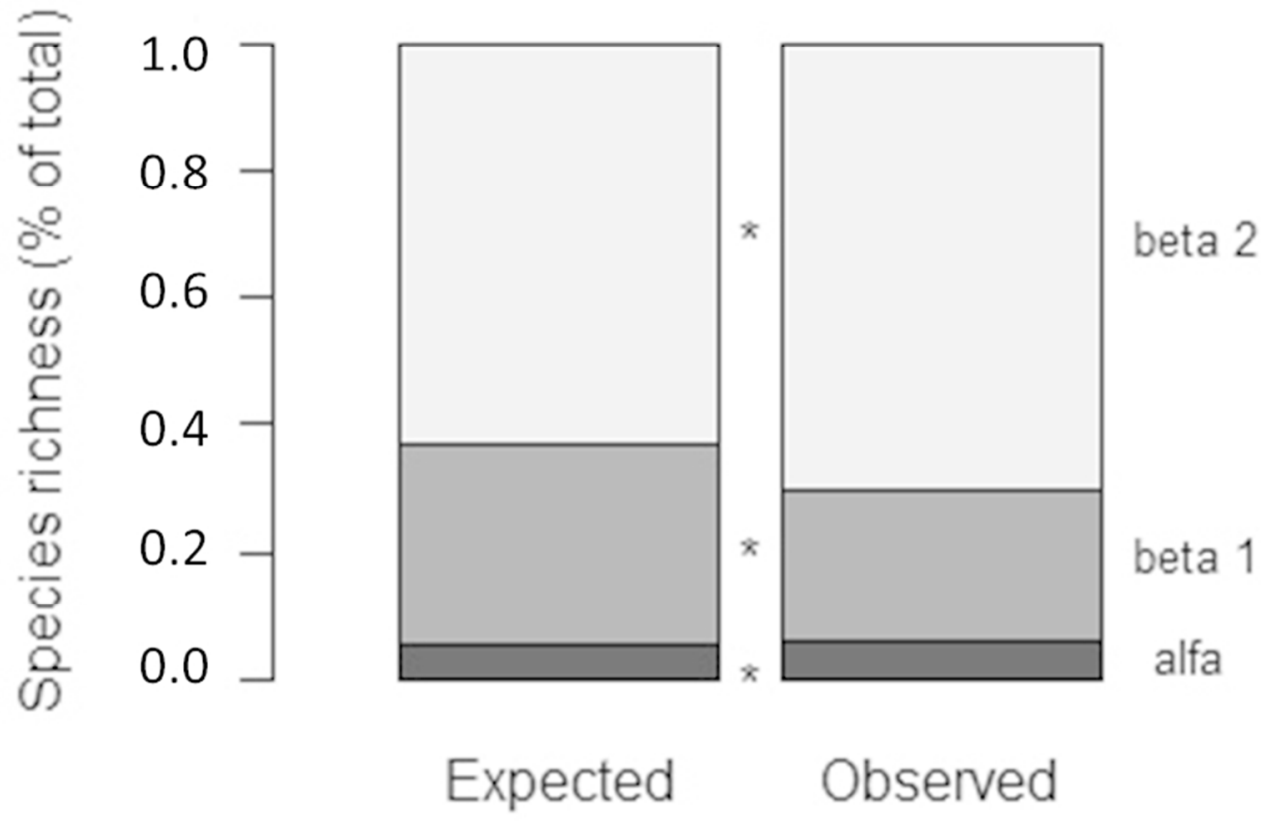

Figure 4. Additive diversity partitioning for the seed bank of an elevation gradient in Serra do Cipó, Brazil. The component a represents the percent of the number of germinated species per plot; $\beta 1$ represents $\beta$ diversity due to the percent of species among plots; $\beta 2$ represents the percent of species among different areas. Observed values were compared statistically with expected values (* means $p<0.001)$.

$69 \times 67 \mathrm{~mm}(300 \times 300 \mathrm{DPI})$ 


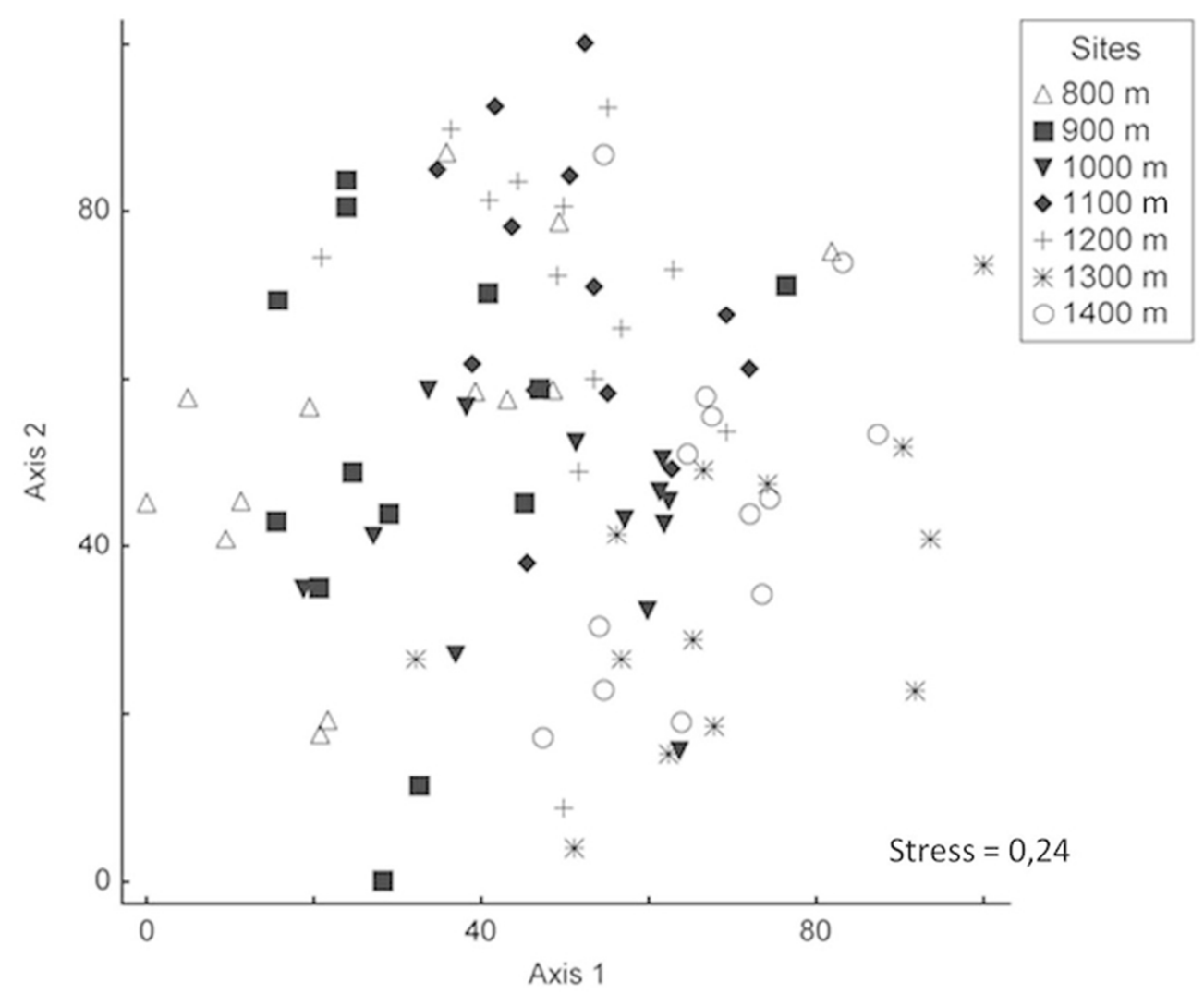

Figure 5. Diagram of nonparametric multidimensional scaling (nMDS) of the species of the seed bank at seven elevations (800-1400 m) in the rupestrian grasslands of Serra do Cipó, Brazil.

$64 \times 56 \mathrm{~mm}(300 \times 300$ DPI $)$ 
A

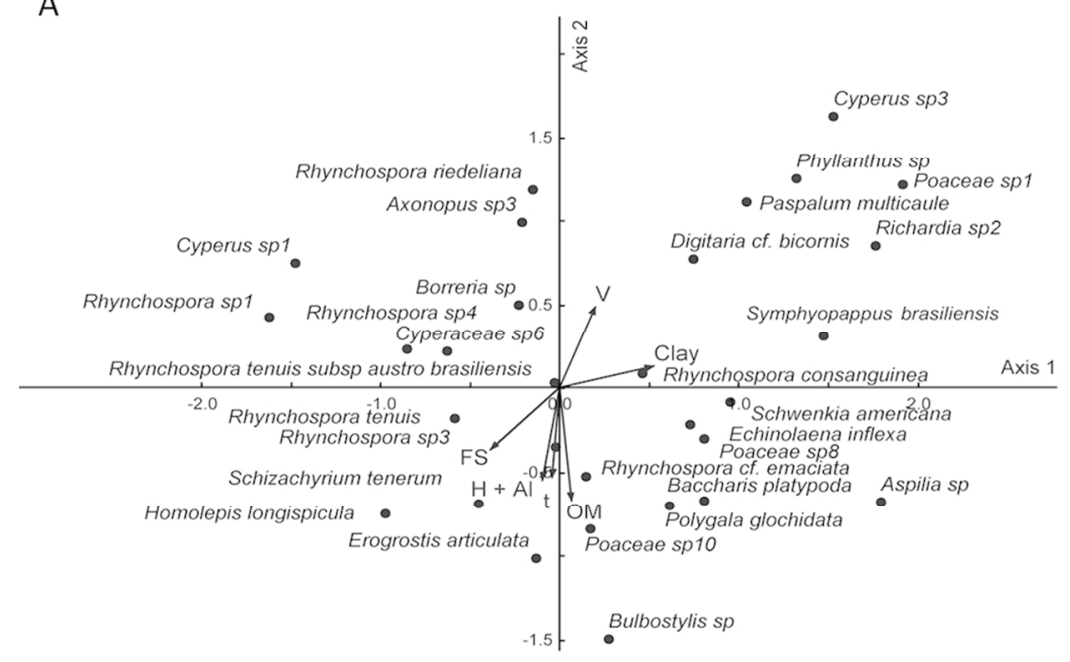

B

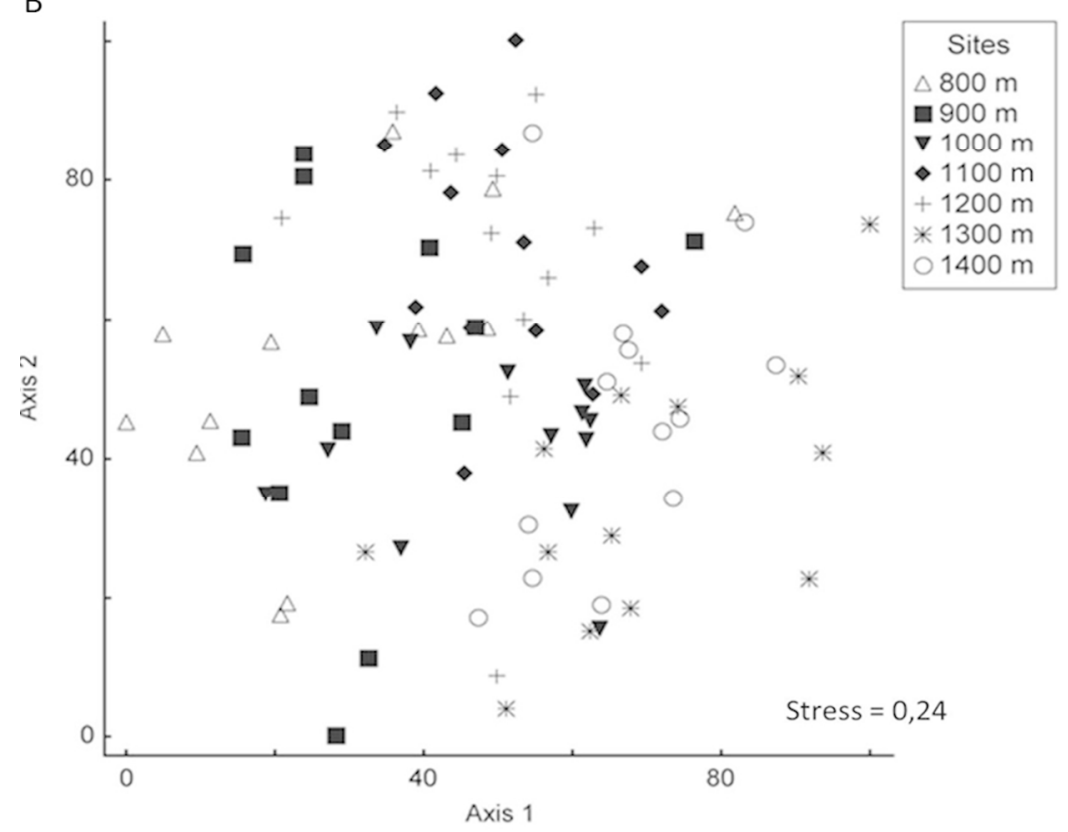

Figure 6. Canonical correspondence analyses (CCA): plot ordination diagrams (A) and seed bank species (B) based on the distribution of the number of individuals of 30 species with 10 or more individuals in 91 plots among seven elevations in rupestrian grasslands in Serra do Cipó, Brazil, and its correlation with soil variables: OM, t, V, H + Al, FS and clay.

$91 \times 136 \mathrm{~mm}(300 \times 300 \mathrm{DPI})$ 
Table A1. Germinated species, their respective families, voucher and occurrence in each area in the evaluated elevation gradient $(800-1400$ m) in Serra do Cipó, Southeastern Brazil.

\begin{tabular}{|c|c|c|c|c|c|c|c|c|c|}
\hline Famíly & Species & 800 & 900 & 1000 & 1100 & 1200 & 1300 & 1400 & Voucher \\
\hline \multirow[t]{2}{*}{ Amaranthaceae } & Alternanthera sp. & & & & & & & $\mathrm{X}$ & 5143 \\
\hline & Amaranthus sp. & & $\mathrm{X}$ & & $\mathrm{X}$ & & & & 5144 \\
\hline \multirow[t]{2}{*}{ Apocynaceae } & Oxypetalum cf. strictum & $\mathrm{X}$ & & & $\mathrm{X}$ & & & & 5145 \\
\hline & $\begin{array}{l}\text { Ageratum fastigiatum } \\
\text { (Gardner) R.M.King \& }\end{array}$ & & & & & & & & 5146 \\
\hline \multirow[t]{11}{*}{ Asteraceae } & H.Rob. & & & & $\mathrm{X}$ & & & & \\
\hline & Aspilia sp. & & $\mathrm{X}$ & & $\mathrm{X}$ & $\mathrm{X}$ & & & \\
\hline & sp. 1 & & $\mathrm{X}$ & & $\mathrm{X}$ & & & $\mathrm{X}$ & \\
\hline & sp. 2 & & $\mathrm{X}$ & $\mathrm{X}$ & & & & & \\
\hline & sp.3 & $\mathrm{X}$ & & & & & & & \\
\hline & sp.4 & $\mathrm{X}$ & & & & $\mathrm{X}$ & & & \\
\hline & $\begin{array}{l}\text { Baccharis platypoda DC. } \\
\text { Baccharis sp.1 }\end{array}$ & $\mathrm{X}$ & $\mathrm{X}$ & $\mathrm{X}$ & $\mathrm{X}$ & $\begin{array}{l}X \\
X\end{array}$ & & & 5147 \\
\hline & $\begin{array}{l}\text { Lychnophora cf. ericoides } \\
\text { Lychnophora pinaster }\end{array}$ & & $\begin{array}{l}X \\
X\end{array}$ & $\mathrm{X}$ & $\mathrm{X}$ & $\mathrm{X}$ & & & 5148 \\
\hline & Senecio sp. & $\mathrm{X}$ & & $\mathrm{X}$ & & $\mathrm{X}$ & & & 5149 \\
\hline & $\begin{array}{l}\text { Symphyopappus } \\
\text { brasiliensis (Gardner) }\end{array}$ & & & & & & & & 5150 \\
\hline & R.M.King \& H.Rob. & $\mathrm{X}$ & $\mathrm{X}$ & $\mathrm{X}$ & $\mathrm{X}$ & $\mathrm{X}$ & & & \\
\hline Bromeliaceae & $\begin{array}{l}\text { sp. } 1 \\
\text { Hedyosmum brasiliense }\end{array}$ & & & $\mathrm{X}$ & & $\mathrm{X}$ & & & \\
\hline Chloranthaceae & Mart. ex Miq. & & $\mathrm{X}$ & & & & & & \\
\hline \multirow[t]{27}{*}{ Cyperaceae } & Bulbostylis cf. conifera & & & & & $\mathrm{X}$ & & & 5151 \\
\hline & Bulbostylis sp. & $\mathrm{X}$ & $\mathrm{X}$ & $\mathrm{X}$ & $\mathrm{X}$ & $\mathrm{X}$ & & & 5152 \\
\hline & sp. 1 & & & & $\mathrm{X}$ & $\mathrm{X}$ & & & \\
\hline & sp.2 & & & & & & $\mathrm{X}$ & & \\
\hline & sp. 3 & & $\mathrm{X}$ & $\mathrm{X}$ & & & & & \\
\hline & sp.4 & & & & & & $\mathrm{X}$ & $\mathrm{X}$ & \\
\hline & sp. 5 & & & $\mathrm{X}$ & $\mathrm{X}$ & & & $\mathrm{X}$ & \\
\hline & sp.6 & $\mathrm{X}$ & & & & $\mathrm{X}$ & $\mathrm{X}$ & & \\
\hline & sp.7 & $\mathrm{X}$ & & & & & & & \\
\hline & sp. 8 & & & & & & $\mathrm{X}$ & & \\
\hline & sp.9 & & & & & & & $\mathrm{X}$ & \\
\hline & sp.10 & & & & & & $\mathrm{X}$ & & \\
\hline & sp.11 & $\mathrm{X}$ & & & & & & & \\
\hline & sp.12 & $\mathrm{X}$ & & & $\mathrm{X}$ & & & & \\
\hline & Cyperus sp.1 & $\mathrm{X}$ & & & & $\mathrm{X}$ & & & 5153 \\
\hline & Cyperus sp. 2 & $\mathrm{X}$ & & & & & & & \\
\hline & Cyperus sp. 3 & $\mathrm{X}$ & & & & & & & 5154 \\
\hline & Cурегus sp.4 & $\mathrm{X}$ & & $\mathrm{X}$ & & & & & 5155 \\
\hline & Cyperus sp.5 & $\mathrm{X}$ & & & $\mathrm{X}$ & & & & \\
\hline & Fimbristylis sp. & $\mathrm{X}$ & $\mathrm{X}$ & & & $\mathrm{X}$ & $\mathrm{X}$ & & 5156 \\
\hline & Lagenocarpus rigidus & & & & & & & & 5157 \\
\hline & Nees & & & & $\mathrm{X}$ & & & & \\
\hline & Lagenocarpus sp. & & & & $\mathrm{X}$ & & & & \\
\hline & Lagenocarpus tenuifolius & & & & & & $\mathrm{Y}$ & $\mathrm{Y}$ & 5158 \\
\hline & Rhynchospora cf. & & $\Lambda$ & & & & $\Lambda$ & $\lambda$ & 5159 \\
\hline & $\begin{array}{l}\text { emaciata } \\
\text { Rhynchospora } \\
\text { consanguinea (Kunth) }\end{array}$ & $\mathrm{X}$ & $\mathrm{X}$ & & $\mathrm{X}$ & $\mathrm{X}$ & $\mathrm{X}$ & $\mathrm{X}$ & 5160 \\
\hline & Boeckeler & $\mathrm{X}$ & $\mathrm{X}$ & $\mathrm{X}$ & $\mathrm{X}$ & $\mathrm{X}$ & $\mathrm{X}$ & $\mathrm{X}$ & \\
\hline
\end{tabular}


Rhynchospora recurvata

(Schrad. ex Nees) Steud.

Rhynchospora riedeliana

C.B.Clarke

Rhynchospora sp.1

Rhynchospora sp.2

Rhynchospora sp. 3

Rhynchospora sp.4

Rhynchospora sp.5

Rhynchospora sp. 6

Rhynchospora tenuis Link

Rhynchospora tenuis

subsp. austro brasiliensis

T.Koyama

Euphorbiaceae

Chamaesyce sp.1

Chamaesyce sp.2

Croton sp. 1

Croton sp. 2

Sp. 1

Chamaecrista desvauxii

Fabaceae

(Collad.) Killip

Mimosa sp.

Stylosanthes sp.

Krameriaceae

Krameria sp.

Hyptis complicata A.St.-

Lamiaceae

Hil. ex Benth.

sp. 1

Diplusodon orbicularis

Lythraceae

Koehne

Malvaceae

sp. 1

sp. 2

sp. 3

Melastomataceae

Cambessedesia $\mathrm{sp}$

Marcetia taxifolia (A.St.-

Hil.) DC.

sp. 1

sp. 2

sp. 3

sp. 4

sp. 5

sp.6

Miconia sp.1

Miconia sp. 2

Microlicia sp.1

Microlicia sp.2

Tibouchina heteromalla

(D.Don) Cogn.

Trembleya laniflora

(D.Don) Cogn.

Myrtaceae

sp. 1

Phyllantaceae

Phyllanthus sp. 1

Phyllanthus sp.2

Axonopus aureus P.

Poaceae

Beauv.

Axonopus siccus (Nees)

Kuhlm.

Axonopus sp.3

Axonopus sp.4

Axonopus sp.5

Digitaria cf. bicornis

$\begin{array}{lllllll} & & \mathrm{X} & & & & \\ \mathrm{X} & \mathrm{X} & \mathrm{X} & \mathrm{X} & \mathrm{X} & \mathrm{X} & \mathrm{X} \\ & & & \mathrm{X} & \mathrm{X} & & \mathrm{X} \\ & \mathrm{X} & & & & & \mathrm{X} \\ \mathrm{X} & \mathrm{X} & \mathrm{X} & \mathrm{X} & \mathrm{X} & \mathrm{X} & \mathrm{X} \\ \mathrm{X} & \mathrm{X} & \mathrm{X} & \mathrm{X} & \mathrm{X} & \mathrm{X} & \mathrm{X} \\ \mathrm{X} & & & & & & \\ & & & & & & \mathrm{X} \\ \mathrm{X} & \mathrm{X} & \mathrm{X} & \mathrm{X} & \mathrm{X} & \mathrm{X} & \mathrm{X}\end{array}$

5161

5162

5164

5165

5166

$\begin{array}{lllll}X & X & X & X & X\end{array}$

5167

X

5168

$\mathrm{X}$

$\mathrm{X}$

X

5169

5170

X X

X

X $\quad \mathrm{X}$

X

X

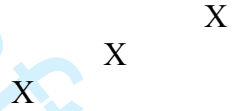

X

X

X

$\mathrm{X}$

X

X

$\mathrm{X}$

X

$x \quad X \quad X$

X

X

X

X

$\begin{array}{llll} & X & & \\ X & X & X & X\end{array}$

X X

X

X

$\mathrm{X}$ X $\mathrm{X}$

X $\quad X \quad X$

$\begin{array}{llllll} & & X & & & \\ X & X & X & X & X\end{array}$ 
Echinolaena inflexa

(Poir.) Chase

Eragrostis articulata

(Schrank) Nees

Homolepis longispicula

(Döll) Chase

Mesosetum loliiforme

(Hochst.) Chase

Panicum cyanescens Nees ex Trin.

Panicum sp

Paspalum erianthum

Nees ex Trin.

Paspalum hyalinum Nees ex Trin.

Paspalum multicaule

Poir.

Paspalum sp.1

Paspalum sp. 3

Paspalum sp.4

Paspalum sp. 5

sp. 1

sp. 3

sp. 4

sp. 5

sp. 6

sp. 7

sp. 8

sp. 9

sp. 10

sp. 11

sp. 12

sp. 14

Schizachyrium cf.

sanguineum

Schizachyrium sp.1

Schizachyrium sp.2

Schizachyrium sp.3

Schizachyrium sp.4

Schizachyrium tenerum

Nees

Trachypogon spicatus

(L.f.) Kuntze

Tatianyx arnacites (Trin.)

Zuloaga \& Soderstr.

Polygala glochidata

Polygalaceae

Portulacaceae Rubiaceae
Kunth

Portulaca cf. oleracea

Borreria sp.1

Borreria sp.2

Declieuxia sp. 1

Declieuxia sp. 2

Diodella apiculata

(Willd. ex Roem. \&

Schult.) Delprete

Richardia sp.1

Richardia sp.2

sp. 1

sp. 2

sp. 3

$\begin{array}{ccccccc}X & X & X & X & X & X & X \\ X & X & X & X & X & & X \\ X & X & X & & X & X & X \\ & X & & X & & & \\ & & & & X & X & \\ & & & & & \end{array}$

5176

5182

X

5186

5185

5187

5188

$\begin{array}{llll} & & X & \\ X & & X & X \\ & X & & \\ & & X & \end{array}$

$\mathrm{X}$

$\mathrm{X}$

$\mathrm{X}$

$\mathrm{X}$

$\mathrm{X}$

$\mathrm{X}$

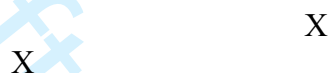

5189

X

X

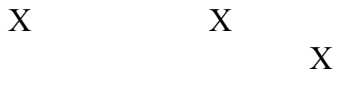

5190

X $\quad$ X $\quad$ X $\quad$ X

X

X

X $\quad$ X

X X

X $\quad X$

5195

X

5197

5198 


\begin{tabular}{|c|c|c|c|c|c|c|c|}
\hline \multirow{3}{*}{ Solanaceae } & Schwenckia americana & \multirow{3}{*}{\multicolumn{2}{|c|}{$X$}} & \multirow{3}{*}{$\mathrm{X}$} & & & \multirow[t]{2}{*}{5199} \\
\hline & Rooyen ex L & & & & $\mathrm{X}$ & & \\
\hline & Solanum sp. & & & & $\mathrm{X}$ & & 5200 \\
\hline Turneraceae & Turnera sp.1 & & & & & & \\
\hline & Turnera sp.2 & & $\mathrm{X}$ & & & & 5201 \\
\hline Xyridaceae & Xyris sp & & & & & $\mathrm{X}$ & \\
\hline Unidentified & sp. 1 & & $\mathrm{X}$ & & & & \\
\hline & sp. 2 & $\mathrm{X}$ & & & & & \\
\hline & sp. 3 & & & & $\mathrm{X}$ & & \\
\hline & sp.4 & & $\mathrm{X}$ & & & & \\
\hline & sp. 5 & & $\mathrm{X}$ & & & & \\
\hline & sp. 6 & & & $\mathrm{X}$ & & & \\
\hline & sp.7 & & & $\mathrm{X}$ & & & \\
\hline & sp. 8 & & & & $\mathrm{X}$ & & \\
\hline & sp.9 & & $\mathrm{X}$ & & $\mathrm{X}$ & & \\
\hline
\end{tabular}

